\title{
Assessment of Gaseous and Particulate Emissions of a Euro 6d-Temp Diesel Vehicle Driven $>1300$ km Including Six Diesel Particulate Filter Regenerations
}

\author{
Victor Valverde $(\mathbb{D}$ and Barouch Giechaskiel * \\ European Commission-Joint Research Centre (JRC), 21027 Ispra, Italy; victor.valverde-morales@ec.europa.eu \\ * Correspondence: barouch.giechaskiel@ec.europa.eu; Tel.: +39-0332-78-5312
}

Received: 29 May 2020; Accepted: 16 June 2020; Published: 17 June 2020

\begin{abstract}
Diesel-fueled vehicles have classically had high particulate and $\mathrm{NO}_{\mathrm{x}}$ emissions. The introduction of Diesel Particulate Filters (DPFs) and Selective Catalytic Reduction for $\mathrm{NO}_{\mathrm{x}}$ (SCR) systems have decreased the Particle Number $(\mathrm{PN})$ and $\mathrm{NO}_{\mathrm{x}}$ emissions, respectively, to very low levels. However, there are concerns regarding the emissions released during the periodic DPF regenerations, which are necessary to clean the filters. The absolute emission levels and the frequency of the regenerations determine the contribution of regenerations, but where they happen (city or highway) is also important due to different contributions to human exposure. In this study, we measured regulated and non-regulated emissions of a Euro 6d-temp vehicle both in the laboratory and on the road. $\mathrm{PN}$ and $\mathrm{NO}_{\mathrm{x}}$ emissions were similar in the laboratory and on-the road, ranging around $10^{10} \mathrm{p} / \mathrm{km}$ and $50 \mathrm{mg} / \mathrm{km}$, respectively. Six regeneration events took place during the $1300 \mathrm{~km}$ driven, with an average distance between regeneration events of only $200 \mathrm{~km}$. During regeneration events, the laboratory limits for $\mathrm{PN}$ and $\mathrm{NO}_{\mathrm{x}}$, although not applicable, were exceeded in one of the two measured events. However, the on-road emissions were below the applicable not-to-exceed limits when regenerations occurred. The weighted $\mathrm{PN}$ and $\mathrm{NO}_{x}$ emissions over the regeneration distance were approximately two times below the applicable limits. The $\mathrm{N}_{2} \mathrm{O}$ emissions were $<14 \mathrm{mg} / \mathrm{km}$ and $\mathrm{NH}_{3}$ at instrument background level $(<1 \mathrm{ppm})$, reaching $8 \mathrm{ppm}$ only during regeneration. The results of this study indicate that due to the short interval between regenerations, studies of diesel vehicles should report the emissions during regeneration events.
\end{abstract}

Keywords: air pollution; vehicle emissions; Diesel Particulate Filter (DPF); regeneration; sub-23 nm; Selective Catalytic Reduction for $\mathrm{NO}_{x}(\mathrm{SCR})$; ammonia $\mathrm{NH}_{3}$; nitric oxide $\mathrm{N}_{2} \mathrm{O}$

\section{Introduction}

Air pollution is one of the main environmental threats worldwide as it impacts ecosystems [1], economic activities [2], and human health [3]. Short and long-term exposure to elevated concentrations of Particulate Matter (PM) and nitrogen dioxide $\left(\mathrm{NO}_{2}\right)$ in the air have been associated with respiratory [4] and cardiovascular [5] diseases, hypertension and diabetes [6], and carcinogenicity [7]. Recently, long-term exposure to elevated levels of fine $\mathrm{PM}\left(\mathrm{PM}_{2.5}\right)$ and $\mathrm{NO}_{2}$ have also been associated with an increase in the mortality rate from COVID-19 (coronavirus disease 2019) [8-11]. Air pollution has been identified as the most relevant public health risk in European cities with strong associations between $\mathrm{PM}$ and $\mathrm{NO}_{2}$ concentrations in the air, population density, and road transport emissions [12,13]. The share of European population exposed to concentrations exceeding the WHO (World Health Organization) air quality guideline annual mean $\mathrm{PM}_{2.5}\left(>10 \mu \mathrm{g} / \mathrm{m}^{3}\right)$ and $\mathrm{NO}_{2}\left(>40 \mu \mathrm{g} / \mathrm{m}^{3}\right)$ in 2017 were $77 \%$ and $7 \%$, respectively. Furthermore, densely populated and heavily trafficked cities such as London, Paris, Torino, and Munich, averaged an annual mean $\mathrm{NO}_{2}$ concentration above $80 \mu \mathrm{g} / \mathrm{m}^{3}$ 
with $86 \%$ of the annual $\mathrm{NO}_{2}$ exceedances located in traffic stations [14]. Road transport is one of the main sources of $\mathrm{PM}_{2.5}$ and $\mathrm{NO}_{\mathrm{x}}$ emissions in the European Union (EU) with $11 \%$ and $39 \%$ of the total emissions, respectively [14]. The contribution of $\mathrm{PM}_{2.5}$ and $\mathrm{NO}_{\mathrm{x}}$ emissions from traffic increase at the city level reaching, for example, 54\% and 47\% in Madrid [15], 54\% and 62\% in Paris [16], and 30\% and $49 \%$ in London [17], respectively. During lockdown periods due to COVID-19, reductions of 50\% of $\mathrm{NO}_{x}$ emissions and $50 \%$ of $\mathrm{NO}_{2}$ concentration in the air have been reported in China and Spain, respectively [18,19], further highlighting the contribution of road transport to air quality.

The EU regulation was recently updated to cover the shortcomings of the older regulation and test cycle (UNECE Regulation 83), which was the homologation test procedure under which Euro 5 and Euro 6b vehicles were type-approved. The new laboratory test procedure (EU regulation 2017/1151), the Worldwide harmonized Light-duty vehicles Test Procedure (WLTP), and the Real-Driving Emissions (RDE) regulation (EU regulation 2017/1151) have been enforced since September 2017. The RDE is an on-road test where $\mathrm{NO}_{\mathrm{x}}$ and solid Particle Number (PN) emissions have not-to-exceed (NTE) certain limits on a test route that complies with a set of testing requirements (e.g., duration 90-120 min, a given share of urban, rural, and motorway operation, ambient temperature between $-7{ }^{\circ} \mathrm{C}$ and $35^{\circ} \mathrm{C}$ ), while instantaneous emissions are being measured with a Portable Emissions Measurement System (PEMS). The NTE takes into account the Conformity Factor (CF), defined as $1+$ margin, which is a parameter that takes into account the additional measurement uncertainties introduced by the PEMS compared to laboratory grade equipment [20]. Vehicles homologated under the WLTP and the RDE procedures belong to the Euro 6d emissions standard (Euro 6d-temp during the phasing in period 2017-2020).

The European fleet of passenger cars accounts for more than 260 million vehicles with an average age of 11 years, and a motorization rate of 512 vehicles per 1000 inhabitants [21]. As of year 2017, the fleet is characterized by a large percentage of diesel-fueled vehicles $(42 \%)$, and an approximate share of $22 \%$ of Euro 5 and $11 \%$ Euro $6 \mathrm{~b}$ vehicles, and $66 \%$ of pre-Euro 5 vehicles [21]. Thus, vehicles type-approved after the entry into force of the RDE regulation represent a small percentage of the fleet, considering that the sales per year in Europe are around 15 million.

There was strong evidence that $\mathrm{NO}_{x}$ emissions from diesel vehicles complying with the Euro 5 and Euro 6 pre-RDE emissions standards were up to 4-7 times higher on the road than the permissible laboratory limits [22-25]. This discrepancy could be explained by the use of cycle-beating strategies in a few cases [26]. In most cases, though, the engine and the after-treatment systems calibration was mainly covering the laboratory homologation test conditions but not other conditions typically encountered on the road. On-road calibration has to cover a wide range of ambient conditions (temperature, altitude) and driving events (e.g., speed bumps, traffic, higher vehicle dynamics, altitude) [27-29], and is therefore more demanding. The widespread introduction of Selective Catalytic Reduction for $\mathrm{NO}_{x}(\mathrm{SCR})$ systems using urea to reduce $\mathrm{NO}_{\mathbf{x}}$ [30] and proper optimization for a big part of the engine map, has resulted in low $\mathrm{NO}_{x}$ emissions.

A laboratory limit for solid PN larger than $23 \mathrm{~nm}$ was introduced in 2011 for diesel vehicles in the Euro $5 \mathrm{~b}$ stage to complement the PM mass requirement. The introduction of the $6 \times 10^{11} \mathrm{p} / \mathrm{km}$ limit forced the general use of Diesel Particulate Filters (DPF) on diesel passenger cars in Europe [31]. DPFs have very high filtration efficiencies and can reduce the engine out soot emission levels of $>95 \%$ [31,32]. The PN emissions of diesel Euro 5 and Euro 6 vehicles fitted with a DPF when tested on the road have been reported to be well below $6 \times 10^{11} \mathrm{p} / \mathrm{km}[23,33-36]$. As soot accumulates on the DPF, the filter requires a regeneration in order to oxidize the deposited soot. Regeneration events increase the emissions of PN and also other gaseous pollutants [37], a situation that has been brought to the attention of environmental organizations [38] as the current regulation does not explicitly limit the emissions that occur during regenerations. For the laboratory tests, the emissions during regeneration are taken into account, weighted by the distance between regeneration events, with the so called ki factor, for $\mathrm{CO}, \mathrm{NO}_{\mathrm{x}}, \mathrm{HC}+\mathrm{NO}_{\mathrm{x}}$, and PM, but not for PN. The reason for not including PN in 2011 was that the contribution of regeneration on PN emissions was negligible [31,39], and more studies were needed to assess the accuracy of the PN systems during regeneration events. Since then, many studies 
have demonstrated that the regeneration events contribute significantly, but nevertheless the PN systems are robust and reliable [40]. However, studies regarding the accuracy of PN systems below $23 \mathrm{~nm}$, which is the current regulated lower particle size, are limited [41]. According to the RDE regulation, in case a regeneration takes place during an official emissions on-road test, the test can be voided and repeated. However, in case a subsequent regeneration occurs during the repetition of the test, pollutants (i.e., $\mathrm{NO}_{\mathrm{x}}$ and $\mathrm{PN}$ for $\mathrm{RDE}$ ) emitted during the repeated test are considered in the emissions evaluation.

Ammonia $\left(\mathrm{NH}_{3}\right)$, which is currently an unregulated pollutant for passenger cars in Europe, plays a relevant role in the formation of secondary particles in the form of ammonium nitrate and ammonium sulfate [42], which can contribute to air pollution in the cities and modify the radiation budget at regional to global scales [43]. A recent study concluded that the control of vehicular VOC (Volatile Organic Compounds) and $\mathrm{NH}_{3}$ emissions might be a more effective way to degrade $\mathrm{PM}_{2.5}$ problems than the control of $\mathrm{NO}_{\mathbf{x}}$ [44]. In the current climate change context, the emissions of unregulated greenhouse gases like $\mathrm{N}_{2} \mathrm{O}$ and $\mathrm{CH}_{4}$ with global warming potentials of 265 and 28 $\mathrm{CO}_{2}$ equivalent, respectively [43], are important and only limited information is available regarding emissions from modern diesel vehicles.

The objective of this research was twofold: (i) to assess regulated and non-regulated tailpipe emissions of a state of the art technology Euro 6d-temp diesel vehicle, under a wide range of driving conditions in the laboratory and on the road, and (ii) to investigate the emissions associated with the regeneration of the DPF. There is a lack of information on both topics, especially for what regards emissions performance of Euro 6-temp vehicles. Despite representing a small proportion of the circulating fleet, vehicles type-approved after the entry into force of the RDE and WLTP regulations shall become widespread with the turnover of the fleet, and it is therefore critical to assess their emissions performance to properly understand their contribution to air pollution. According to our knowledge, studies on diesel Euro 6-temp vehicles with state-of-the art aftertreatment architecture are limited [45,46].

This paper is organized as follows: Section 2 describes the characteristics of the vehicle, the instrumentation used, and provides details on the laboratory and on-road tests performed. Section 3 presents the regulated and non-regulated emissions over the complete cycles, and as instantaneous values during selected events. Section 4 discusses emissions at cold start, and the frequency of the DPF regenerations and its contribution to the total vehicle emissions. Conclusions are given in Section 5.

\section{Experiments}

\subsection{Vehicle and Fuel}

The vehicle was powered by an internal combustion diesel engine with a displacement of $2.1 \mathrm{~L}$ and a rated power of 200 horse-power. The vehicle had an 8-speed automatic gearbox and was 2-axle powered with all-wheel (AWD) and rear-wheel (RWD) selectable drive modes. The 2018 model-year vehicle met the Euro 6d-temp emissions standard and was type-approved as a passenger car (multipurpose vehicle), category M1 (vehicles used for carriage of passengers, comprising not more than eight seats). The emissions control system included an Exhaust-Gas Recirculation (EGR) system, a Diesel Oxidation Catalyst (DOC), a Selective-Catalytic Reduction (SCR) catalyst for $\mathrm{NO}_{\mathbf{x}}$ and a Diesel Particulate Filter (DPF). Additional details of the vehicle are provided in Table 1.

Prior to the start of the testing, the vehicle was physically inspected and an OBD (On-Board Diagnostics) scan tool was used at the OBD of the vehicle. No malfunctions or errors were identified during the inspection. All laboratory tests were performed in AWD mode using the road loads declared by the manufacturer in the Certificate of Conformity $(\mathrm{CoC})$. On the road, a combination of AWD and RWD modes were used for the different tests. The vehicle fitted all-seasons tires in all tests. Market 
biodiesel fuel B7, i.e., with max 7\% Fatty Acid Methyl Ester (FAME) was used for all laboratory and on-road tests with $7 \mathrm{ppm}$ sulfur content and $3.6 \%$ polyaromatics.

Table 1. Vehicle general features.

\begin{tabular}{cc}
\hline Vehicle Category & M1 \\
\hline Propulsion type & Internal combustion engine \\
Cylinder number and arrangement & 4 in line \\
Combustion type & Compression ignition \\
Fuel type & Diesel \\
Injection type & Direct injection \\
Aspiration type & Turbocharger \\
Emissions control technologies & EGR+DOC+SCR+DPF \\
Engine displacement $(\mathrm{L})$ & 2.1 \\
Engine power $(\mathrm{hp})$ & 200 \\
Transmission/Gearbox & Automatic/8 \\
Mass in running order $(\mathrm{kg})$ & 2000 \\
Declared CO 2 (WLTP) $(\mathrm{g} / \mathrm{km})$ & 249 \\
EU emission standard & Euro $6 \mathrm{~d}-\mathrm{temp}$ \\
Registration date & $05 / 2018$ \\
Mileage $(\mathrm{km})$ & 3000 \\
\hline
\end{tabular}

DOC $=$ Diesel Oxidation Catalyst; DPF = Diesel Particulate Filter; EGR = Exhaust Gas Recirculation; SCR $=$ Selective Catalytic Reduction for $\mathrm{NO}_{x}$; WLTP $=$ Worldwide harmonized Light vehicles Test Procedure. M1: vehicles used for carriage of passengers, comprising not more than eight seats.

\subsection{Laboratory Tests}

The laboratory emission tests were performed at JRC's (Joint Research Centre) vehicle emissions laboratory (VELA 2). The tests were conducted according to the Worldwide harmonized Light vehicles Test Procedure (WLTP) with cold engine start, i.e., the lubricant oil temperature was within $1{ }^{\circ} \mathrm{C}$ from the ambient temperature at the start of the test. The respective cycle was the Worldwide Light-duty Test Cycle (WLTC). The laboratory ambient temperature was set to $0^{\circ} \mathrm{C}, 14^{\circ} \mathrm{C}, 23^{\circ} \mathrm{C}$ or $30^{\circ} \mathrm{C}$. The WLTP, in addition to the new test cycle, respected all provisions from Commission Regulation (EU) 2017/1151 including the preconditioning and soaking requirements for the $23^{\circ} \mathrm{C}$ tests.

The whole exhaust gas was diluted in a dilution tunnel with Constant Volume Sampling (CVS) equipped with critical flow venturi to measure total air flow and a SAO (Smooth-Approach Orifice) to measure dilution air flow. Gas analyzers (MEXA 7400, Horiba, Kyoto, Japan) were measuring from the dilution tunnel in real time. A small part of the diluted gas was also collected in bags and was analyzed for the gaseous pollutants as required in the regulation (Figure 1). The principle of operation of the analyzers was: non-dispersive infrared detection for $\mathrm{CO}$ and $\mathrm{CO}_{2}$, chemiluminescence for $\mathrm{NO}_{\mathrm{x}}$, and hot $\left(191^{\circ} \mathrm{C}\right)$ flame ionization detection for total hydrocarbons (THC) and methane $\left(\mathrm{CH}_{4}\right)$.

A Fourier Transform Infrared Spectrometer (FTIR) (Sesam i60 from AVL, Austria, Graz) with a heated polytetrafluoroethylene sampling line at $191{ }^{\circ} \mathrm{C}$ was sampling from the tailpipe, to characterize non-regulated pollutants. The data acquisition frequency was $1 \mathrm{~Hz}$. Compounds measured, among others, included $\mathrm{NH}_{3}, \mathrm{~N}_{2} \mathrm{O}$, formaldehyde $(\mathrm{HCHO})$, acetaldehyde $\left(\mathrm{CH}_{3} \mathrm{CHO}\right)$ and isocyanic acid (HNCO).

The solid Particle Number (PN) emissions were measured from the full dilution tunnel with an AVL (Graz, Austria) Particle Counter (APC 489) [47]. The system had a hot dilution $\left(150{ }^{\circ} \mathrm{C}\right)$, an evaporation tube $\left(350^{\circ} \mathrm{C}\right)$ and a secondary diluter at ambient temperature. Solid particles were counted with a Condensational Particle Counter (CPC) model 3790 from TSI Inc. (Shoreview, MN, USA), having a counting efficiency of $50 \%$ at $23 \mathrm{~nm}$. In addition, a CPC with $50 \%$ counting efficiency at $10 \mathrm{~nm}$ (model 3010, TSI Inc.) was sampling from APC's secondary dilution exhaust outlet. No particle correction was applied for the sub- $23 \mathrm{~nm}$ particles, as this will not be required in the future $>10 \mathrm{~nm}$ regulation. 


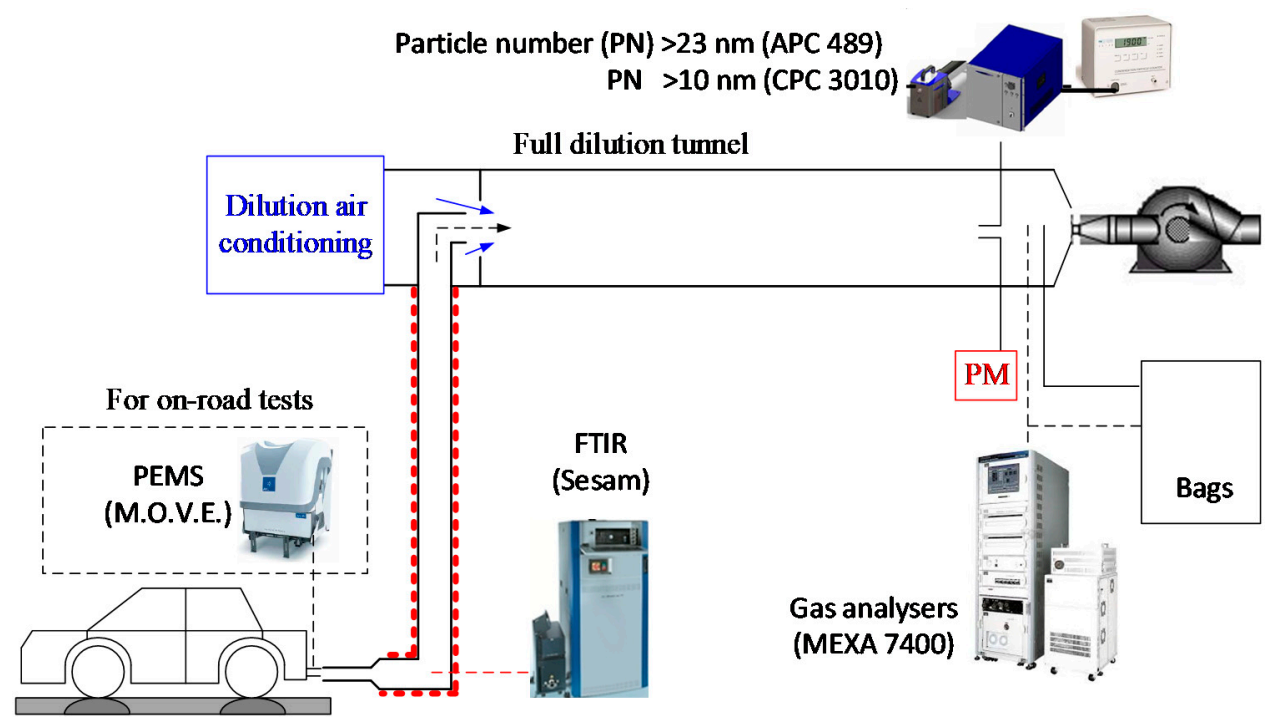

Figure 1. Experimental setup. APC $=$ AVL Particle Counter; $\mathrm{CPC}=$ Condensation Particle Counter; FTIR $=$ Fourier Transform Infrared Spectrometer; PEMS = Portable Emissions Measurement System; $\mathrm{PM}=$ Particulate Matter mass; $\mathrm{PN}=$ Particle Number.

The PM mass was determined using a filter holder heated at $47^{\circ} \mathrm{C}$. A single filter was used for the whole measurement campaign in the laboratory in order to collect high enough mass on the filter and to minimize the influence of volatile species condensing on the filter. Even though this approach was not following the technical requirements described in the WLTP for particle mass (one filter is required per test), it should give a good estimation of the mean mass emissions.

Some engine and vehicle parameters (such as engine speed and coolant temperature) were logged through the OBD port at $1 \mathrm{~Hz}$ frequency.

\subsection{On-Road Tests}

The Portable Emissions Measurement System (PEMS) used was the MOVE (model 2016) from AVL, fulfilling the performance requirements from the real-driving emissions (RDE) Commission Regulation (EU) 2017/1151. It consisted of an Exhaust Flow Meter (EFM), exhaust gas analyzers and a solid particle counter and heated exhaust lines, a GPS (Global Positioning System) antenna, and a weather station measuring ambient temperature, pressure and relative humidity. The PEMS measured the exhaust gas concentrations of $\mathrm{CO}$ and $\mathrm{CO}_{2}$ with a non-dispersive infrared analyzer, and $\mathrm{NO}$ and $\mathrm{NO}_{2}$ with a non-dispersive ultra-violet analyzer (with independent chemical cells for $\mathrm{NO}$ and $\mathrm{NO}_{2}$ ). Solid PN $>23 \mathrm{~nm}$ were measured by means of a diffusion charging-based detector downstream of a heated catalytic stripper at $300{ }^{\circ} \mathrm{C}$ [48]. The main PEMS unit was mounted inside the vehicle. The EFM used a Pitot tube (2.5 inches) to measure the exhaust flow rate. The average and maximum on-road measured exhaust flow rate was $133 \mathrm{~kg} / \mathrm{h}$ and $700 \mathrm{~kg} / \mathrm{h}$, respectively. The maximum range of the flow meter $(970 \mathrm{~kg} / \mathrm{h})$ was not exceeded. The mass of the PEMS was circa $135 \mathrm{~kg}$ and the maximum payload of the vehicle was not exceeded.

The tests on the road were performed in February 2020 on public paved roads in the proximity of the laboratories of JRC, over a set of routes within and outside the RDE boundary conditions. Table 2 summarizes the main characteristics of the five routes used. Figure A1 in the Appendix A displays the vehicle speed and altitude profiles of the routes used in the campaign. 
Table 2. On-road routes' characteristics. The values reported for RDE-1 and Traffic routes correspond to the averages of the two repetitions performed.

\begin{tabular}{cccccccc}
\hline & RDE-1 & RDE-2 & RDE-1-D & RDE-2-D & Traffic & Motor-City & Motorway \\
\hline Distance $[\mathrm{km}]$ & 91 & 98 & 91 & 98 & 18 & 129 & 174 \\
Duration $[\mathrm{min}]$ & 101 & 104 & 96 & 101 & 53 & 121 & 100 \\
Mean $\mathrm{T}_{\text {amb }}\left[{ }^{\circ} \mathrm{C}\right]$ & 16 & 9 & 18 & 15 & 8 & 13 & 7 \\
Urban stop time $[\%]$ & 20 & 21 & 18 & 20 & 32 & 16 & 22 \\
Urban dist. $[\mathrm{km}]$ & 34 & 33 & 34 & 31 & 18 & 34 & 11 \\
Rural dist. $[\mathrm{km}]$ & 28 & 31 & 28 & 33 & - & 12 & 11 \\
Motorway dist. $[\mathrm{km}]$ & 28 & 35 & 30 & 35 & - & 83 & 151 \\
Mean speed $[\mathrm{km} / \mathrm{h}]$ & 53.5 & 57 & 57 & 59 & 20.5 & 64 & 104 \\
CPEG [m/100km] & 600 & 740 & 600 & 740 & 990 & 460 & 430 \\
Max altitude $[\mathrm{m}]$ & 300 & 410 & 300 & 410 & 255 & 300 & 330 \\
\hline
\end{tabular}

CPEG = Cumulative Positive Elevation Gain .

The vehicle was driven on two routes (RDE-1 and RDE-2) designed to meet all the criteria from the RDE regulation (trip duration, composition, temperature range, altitude range, cumulative positive elevation gain, etc.). Details on the routes can be found elsewhere [45]. The vehicle was additionally tested on both routes but driven with a more aggressive driving style (RDE-1-D and RDE-2-D), resulting in more dynamic trip indicators (above max. 95th percentile of $\mathrm{v} \times$ a RDE limits, see Figure A2) in the Appendix. Even though the total distance between the normal and dynamic driving routes were the same, the urban, rural and motorway shares were slightly different due to the different speeds, but within typical experimental repeatability. The higher driving dynamics were achieved by performing more stop and go, and faster accelerations after vehicle stops at traffic lights, for example. All tests were performed respecting the Italian road safety code. Additionally, another three non-RDE-compliant routes that represent a combination of motorway-city-motorway drive (Motor-City), a prolonged motorway drive (Motorway) and a driving route simulating congested urban conditions with frequent stop and go situations (Traffic) were used. The traffic route consisted of five loops around the JRC site including several 30-40 s stops, two performed at an average speed (including stops) of $17 \mathrm{~km} / \mathrm{h}$, and three at an average speed of $22 \mathrm{~km} / \mathrm{h}$. One repetition per test was performed except for the Traffic route ( 2 repetitions) and RDE-1 ( 2 repetitions). In one of the two RDE- 1 repetitions, a DPF regeneration took place. Regeneration also took place on the RDE-2-D, Motorway, and Motor-City tests, but these tests were not repeated.

The vehicle was soaked inside a facility at an ambient temperature of circa $18^{\circ} \mathrm{C}$. The ambient temperature during the test campaign ranged from $1{ }^{\circ} \mathrm{C}$ to $21^{\circ} \mathrm{C}$, with an average temperature of $13^{\circ} \mathrm{C}$. No driving occurred in extended temperature conditions (either $<0{ }^{\circ} \mathrm{C}$ or above $30^{\circ} \mathrm{C}$ ) or extended altitude conditions $(>700 \mathrm{~m})$. The start/stop system was used on all tests. Zero and span calibrations were performed systematically prior to and after the test. The zero and span drift were within the permissible drifts defined in the RDE regulation.

\subsection{Calculations}

The laboratory bag results (in $\mathrm{g} / \mathrm{km}$ ) and the second-by-second results from the dilution tunnel (in $\mathrm{g} / \mathrm{s}$ ) were provided by the chassis dynamometer automation software. The calculations were conducted according to the regulation.

Distance-specific emissions of non-regulated pollutants (in $\mathrm{mg} / \mathrm{km}$ ) were calculated from concentrations measured with the FTIR, exhaust mass flow was calculated as the difference between total air and dilution air flows, and distance was inferred from chassis dynamometer vehicle speed. The $\mathrm{CO}_{2}$ and $\mathrm{CH}_{4}$ values calculated from the FTIR were within $\pm 3 \%$ of the bag results, while the $\mathrm{NO}_{x}$ results were within $\pm 20 \%$ (see Figure A3 in the Appendix A for a bag vs. FTIR intercomparison throughout the laboratory campaign).

The PEMS data was extracted into a Microsoft Excel file using AVL CONCERTO [49] Version 502. EMROAD version 6.03 [50] was used to calculate second-by-second emissions (in $\mathrm{g} / \mathrm{s}$ ) or 
distance-specific emissions (in $\mathrm{g} / \mathrm{km}$ ), using the GPS as the source for vehicle speed. A PEMS validation in the chassis dynamometer was performed immediately after the on-road campaign. The differences in gaseous and particle measurements of the PEMS against the laboratory bags were within the permissible tolerances of the RDE regulation: $+10 \mathrm{mg} / \mathrm{km}$ for $\mathrm{NO}_{\mathrm{x}}(+20 \%),+10 \mathrm{~g} / \mathrm{km}$ for $\mathrm{CO}_{2}(+4 \%)$, $<25 \mathrm{mg} / \mathrm{km} \mathrm{CO},-3 \times 10^{10} \mathrm{p} / \mathrm{km}$ for PN $(-21 \%)[51,52]$.

The verification of the overall trip dynamics was done using the moving average window method as prescribed in EU regulation 2018/1832 [53], and using the declared distance-specific WLTP $\mathrm{CO}_{2}$ value as reported in the $\mathrm{CoC}$. The on-road emissions calculated and reported in this investigation are, however, the raw emissions (not corrected for extended conditions and without using the weighting function based on $\mathrm{CO}_{2}$ emissions, as introduced in the fourth package of the RDE regulation EU 2018/1832). These raw emissions include all the emissions from test start to test end including cold start and idling periods. The emissions are compared against the not-to-exceed (NTE) limits for illustration purposes, as emissions compliance necessarily needs to be done against emissions calculated following Appendix 6 of the RDE regulation. For reference, only the two Traffic tests, and the Motorway test would require a 0.65 and 0.8 correction factor, respectively, due to the higher $\mathrm{CO}_{2}$ on the road than in the laboratory, as described in Appendix 6. Note though that corrections and compliance to the limits are applicable only for the RDE-compliant tests.

\section{Results}

\subsection{Laboratory Tests}

Figure 2 summarizes the laboratory $\mathrm{PN}$ and $\mathrm{NO}_{\mathrm{x}}$ results. The $\mathrm{PN}$ emissions (Figure 2a) were almost one order of magnitude below the PN limit $\left(6 \times 10^{11} \mathrm{p} / \mathrm{km}\right)$, at the cold WLTC at $23^{\circ} \mathrm{C}$ and $30^{\circ} \mathrm{C}\left(<7 \times 10^{10} \mathrm{p} / \mathrm{km}\right)$. They were three times higher at cold WLTC with a regeneration event (WLTC $\mathrm{R} 23^{\circ} \mathrm{C}$ ), but still half way from the limit (even though not applicable). They slightly exceeded the limit at the WLTC at $0{ }^{\circ} \mathrm{C}$ and they were four times higher at the WLTC with regeneration at $14{ }^{\circ} \mathrm{C}$. The concentration of $10-23 \mathrm{~nm}$ particles was $11 \%$ to $51 \%$ of the $>23 \mathrm{~nm}$ particles. The highest ratio was noted at $30{ }^{\circ} \mathrm{C}$, where the absolute levels were the lowest. Quite a high percentage (28\%) was also measured at the $14{ }^{\circ} \mathrm{C}$ WLTC with regeneration.

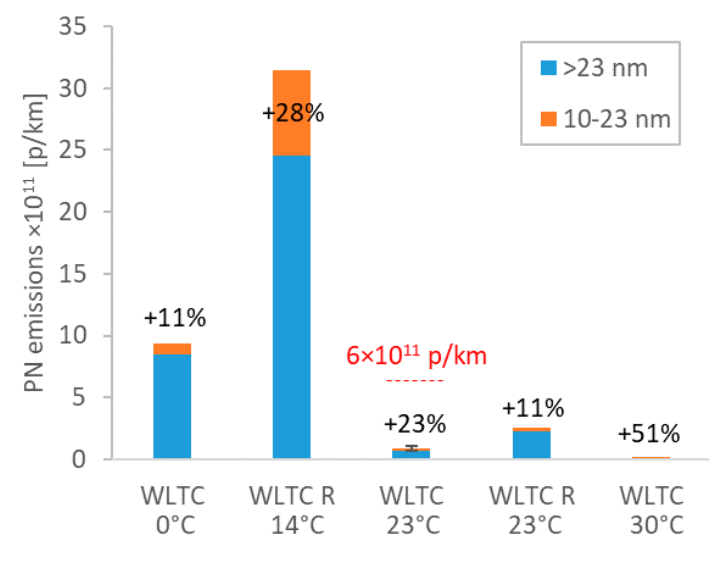

(a)

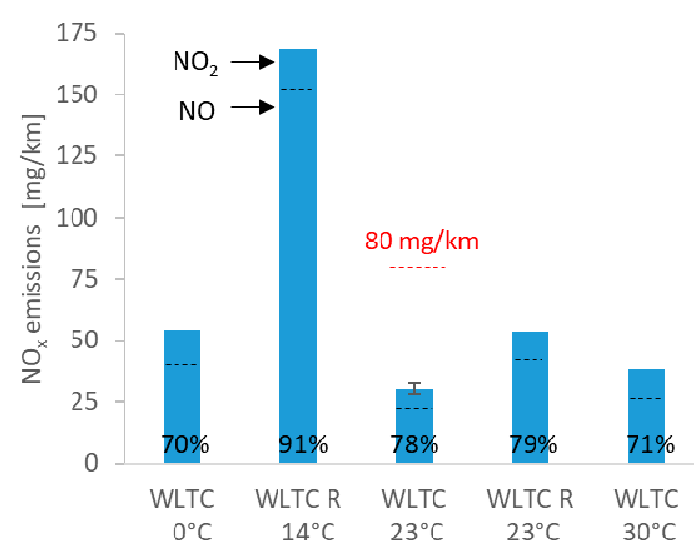

(b)

Figure 2. Emissions during laboratory test over the Worldwide Light-duty Test Cycle (WLTC) at different ambient temperatures: (a) Particle Number $(\mathrm{PN})>23 \mathrm{~nm}$ and $10-23 \mathrm{~nm}$. Percentages give the ratio $10-23 \mathrm{~nm}$ to $>23 \mathrm{~nm}$ PN concentrations; (b) Bag $\mathrm{NO}_{\mathrm{x}}$. Percentage gives the ratio $\mathrm{NO} / \mathrm{NO}_{\mathrm{x}}$ based on the FTIR (Fourier Transform Infrared Spectrometer). Error bars show min-max values of 2 repetitions. The red dotted line gives the laboratory emission limits, when applicable. $\mathrm{R}=$ Regenerating. 
One filter was taken for the whole campaign and the PM mass emissions were $0.84 \mathrm{mg} / \mathrm{km}$. The equivalent PN emissions were approximately $3-4 \times 10^{11} \mathrm{p} / \mathrm{km}$ (for $>23 \mathrm{~nm}$ and $>10 \mathrm{~nm}$, respectively), giving a correlation factor of $3.8-4.8 \times 10^{11} \mathrm{p} / \mathrm{mg}$.

The $\mathrm{NO}_{\mathrm{x}}$ emissions were around $30 \mathrm{mg} / \mathrm{km}$ at the cold WLTC at $23{ }^{\circ} \mathrm{C}$ and $30{ }^{\circ} \mathrm{C}$, and around $50 \mathrm{mg} / \mathrm{km}$ at the WLTC at $0{ }^{\circ} \mathrm{C}$ and the regenerating WLTC at $23{ }^{\circ} \mathrm{C}$, below the limit of $80 \mathrm{mg} / \mathrm{km}$. They exceeded two times the limit (not applicable) at the regenerating WLTC at $14{ }^{\circ} \mathrm{C}$. The $\mathrm{NO} / \mathrm{NO}_{\mathrm{x}}$ ratio varied between $70 \%$ and $91 \%$, without any particular trend between regenerating or non-regenerating cycles.

Figure 3 gives examples of PN and $\mathrm{NO}_{x}$ concentrations for the cold WLTC at $23{ }^{\circ} \mathrm{C}$ with and without regeneration and at $14{ }^{\circ} \mathrm{C}$ with regeneration. High PN emissions were measured at the cold start of the cycle and during the regeneration (Figure 3a). Similarly, for $\mathrm{NO}_{\mathrm{x}}$, high concentrations were measured during cold start and regeneration.

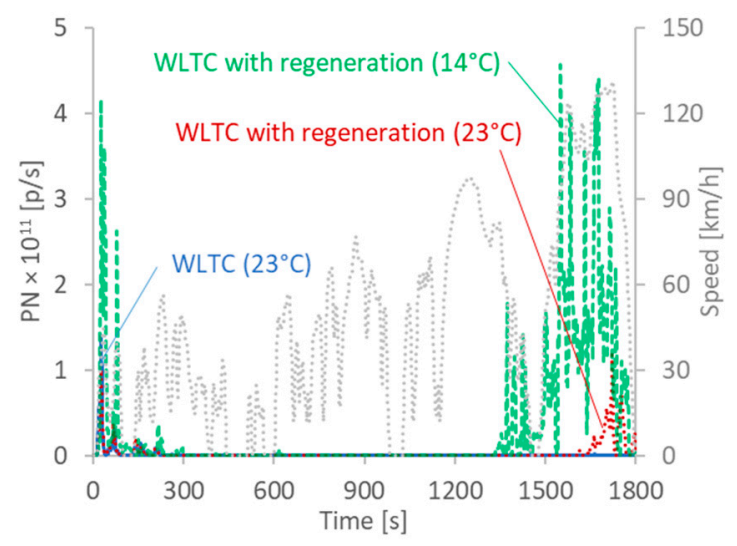

(a)

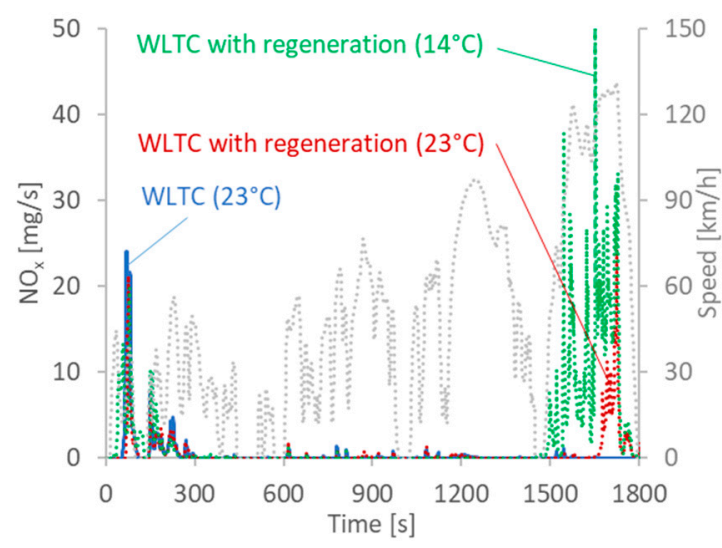

(b)

Figure 3. Real time concentrations over the Worldwide Light-duty Test Cycle (WLTC) at $23^{\circ} \mathrm{C}$ and $14{ }^{\circ} \mathrm{C}$ (with regeneration) as measured from the dilution tunnel: (a) Particle Number (PN) $>23 \mathrm{~nm}$; (b) $\mathrm{NO}_{\mathrm{x}}$.

Figure 4 gives examples of $\mathrm{NH}_{3}$ and $\mathrm{N}_{2} \mathrm{O}$ for the WLTC at $23{ }^{\circ} \mathrm{C}$ and $14{ }^{\circ} \mathrm{C}$ with and without regeneration, as measured with the FTIR from the tailpipe. Regarding $\mathrm{NH}_{3}$ (Figure 4a), the emissions were at the instrument background levels $(<1 \mathrm{ppm})$, except during regeneration, where up to $8 \mathrm{ppm}$ were detected. This would translate to $1 \mathrm{mg} / \mathrm{km}$ for the regenerating cycle. The $\mathrm{N}_{2} \mathrm{O}$ emissions (Figure $4 \mathrm{~b}$ ) were variable over the cycle and the regeneration did not result in a significant increase in $\mathrm{N}_{2} \mathrm{O}$. The average concentration for the WLTC at $23^{\circ} \mathrm{C}$ was $11 \mathrm{mg} / \mathrm{km}\left(2.8 \mathrm{CO}_{2}\right.$-equivalent $)$ and reached $12.5-13.5 \mathrm{mg} / \mathrm{km}$ at the regenerating cycles. Other non-regulated pollutants such as $\mathrm{HCHO}(0.3 \mathrm{mg} / \mathrm{km})$ and $\mathrm{CH}_{3} \mathrm{CHO}(19 \mathrm{mg} / \mathrm{km})$ were low over the WLTC at $23^{\circ} \mathrm{C}$. HNCO averaged $0.35 \mathrm{mg} / \mathrm{km}$ over the WLTC at $23^{\circ} \mathrm{C}$, but ten times higher at $0^{\circ} \mathrm{C}$. Emissions of $\mathrm{CH}_{4}$, which were not particularly affected by ambient temperature $\left(6.5 \mathrm{mg} / \mathrm{km}\right.$ at $0{ }^{\circ} \mathrm{C}, 5.4 \mathrm{mg} / \mathrm{km}$ at $23^{\circ} \mathrm{C}, 5.7 \mathrm{mg} / \mathrm{km}$ at $\left.30^{\circ} \mathrm{C}\right)$, were twice as high during the cycles where a regeneration occurred $\left(12.8 \mathrm{mg} / \mathrm{km}\right.$ at $14{ }^{\circ} \mathrm{C}$ and $12.4 \mathrm{mg} / \mathrm{km}$ at $\left.23^{\circ} \mathrm{C}\right)$. $\mathrm{CH}_{4}$ emissions at $23^{\circ} \mathrm{C}$ corresponded to $<0.2 \% \mathrm{CO}_{2}$-equivalent. $\mathrm{N}_{2} \mathrm{O}$ and $\mathrm{CH}_{4}$ accounted for circa $1 \%$ of the $\mathrm{CO}_{2}$-equivalent of the vehicle on the WLTP $23^{\circ} \mathrm{C}$ test. Table A1 in the Appendix A provides the emissions for regulated and non-regulated pollutants as measured with FTIR from the tailpipe over the WLTC at different ambient temperatures. 


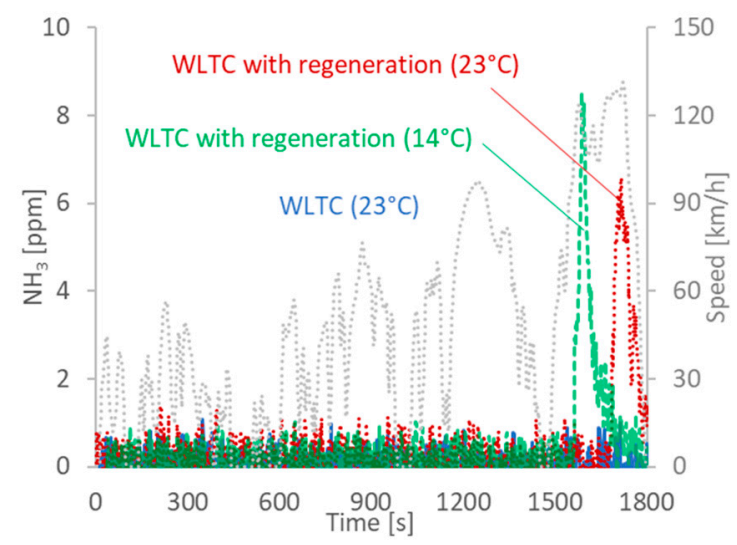

(a)

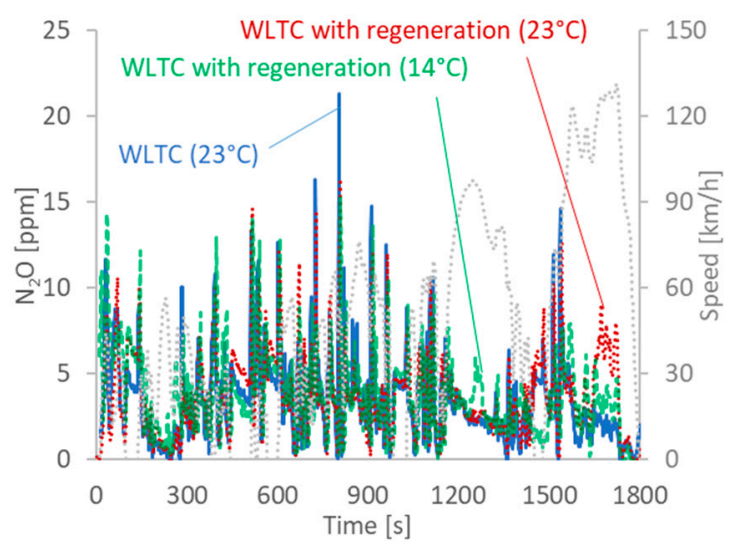

(b)

Figure 4. Real time concentrations over the Worldwide Light-duty Test Cycle (WLTC) at $23{ }^{\circ} \mathrm{C}$ and $14{ }^{\circ} \mathrm{C}$ with and without regeneration: (a) $\mathrm{NH}_{3}$; (b) $\mathrm{N}_{2} \mathrm{O}$. Measurements from the tailpipe with FTIR (Fourier Transform Infrared Spectrometer).

\subsection{On-Road Tests}

Figure 5 summarizes the on-road $\mathrm{PN}$ and $\mathrm{NO}_{\mathrm{x}}$ results. The PN emissions (Figure $5 \mathrm{a}$ ) were very low $2 \times 10^{10} \mathrm{p} / \mathrm{km}$ at normal RDE-compliant or traffic conditions, 3 times higher at RDE dynamic driving (RDE D). They reached on average $2 \times 10^{11} \mathrm{p} / \mathrm{km}$ during RDE trips with regenerations (RDE* $\mathrm{R}$ ). The maximum PN emissions during a regenerating RDE were $4.5 \times 10^{11} \mathrm{p} / \mathrm{km}$, half of the on-road PN limit with a Conformity Factor (CF) 1.5. The scatter at the (complete) dynamic RDEs was due to the different PN levels during the regeneration events. In particular, for the urban part, the scatter was even higher due to one regeneration event taking place in the urban part.

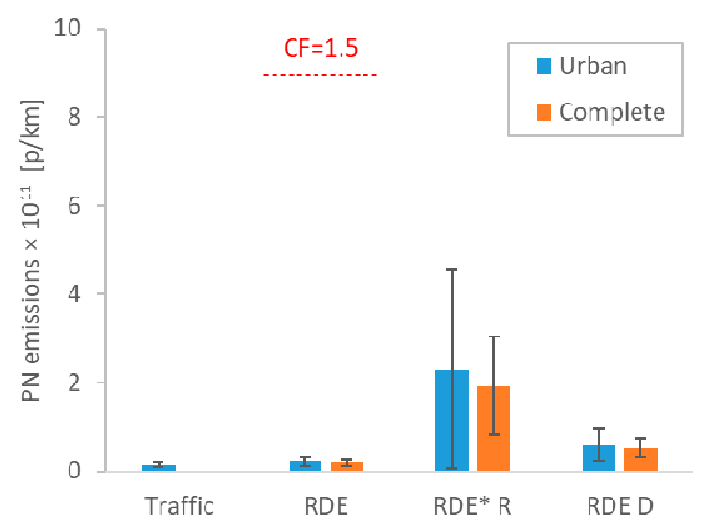

(a)

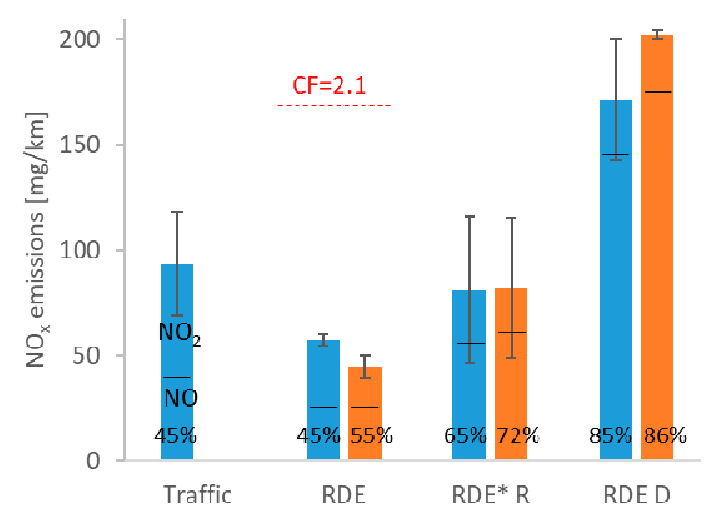

(b)

Figure 5. Emissions during on-road tests for the urban part or the complete trip: (a) Particle Number $(\mathrm{PN})>23 \mathrm{~nm}$; (b) $\mathrm{NO}_{x}$ as sum of $\mathrm{NO}$ and $\mathrm{NO}_{2}$. Percentage gives the ratio $\mathrm{NO} / \mathrm{NO}_{\mathrm{x}}$. "RDE" refers to

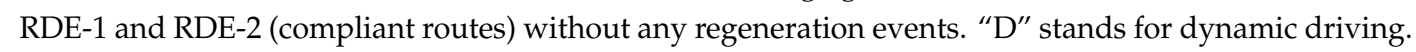
"RDE* R" includes RDE-1, Motor-City and Motorway routes, all with regeneration events. "Traffic" is the urban route with many stop and go. Error bars show min-max values of two or three routes. The red dotted line gives the Real-Driving Emissions (RDE) limit with the Conformity Factor (CF).

The RDE $\mathrm{NO}_{x}$ emissions (Figure $5 b$ ) were below the applicable NTE limit for the specific vehicle (with $\mathrm{CF}=2.1$ ), even the future Euro $6 \mathrm{~d}$ limit with $\mathrm{CF}=1.43$. They were on average below $100 \mathrm{mg} / \mathrm{km}$ at the traffic cycle or even at RDE tests with regenerations, although they could reach $120 \mathrm{mg} / \mathrm{km}$ in some routes. The dynamic driving resulted in emissions of around $200 \mathrm{mg} / \mathrm{km}$. The levels of the 
complete and urban part were similar for the different trips, indicating a good $\mathrm{NO}_{\mathrm{x}}$ management even during urban driving. The $\mathrm{NO} / \mathrm{NO}_{\mathrm{x}}$ ratio varied between $45 \%$ (RDE) and $85 \%$ (dynamic driving).

Figure 6 gives examples of $\mathrm{PN}$ and $\mathrm{NO}_{\mathrm{x}}$ emissions during a DPF regeneration (time $4800 \mathrm{~s}$ until 5300 s). The PN emissions (Figure 6a) increased 2-3 orders of magnitude from baseline levels. The regeneration was initiated at the motorway part of the RDE test. During the regeneration, there was a stop (toll in the highway) where the vehicle was idling. Nevertheless, the regeneration continued and finished the regeneration at the second part of the motorway phase. Then, the emissions remained relatively elevated until the end of the test as the DPF was empty and the filtration efficiency low. The $\mathrm{NO}_{\mathrm{x}}$ (Figure $6 \mathrm{~b}$ ) had a similar behavior.

Examples of normal and dynamic driving at the rural and motorway parts are given in Figure 7. During normal driving (Figure 7a), the $\mathrm{NO}_{\mathrm{x}}$ emissions during rural driving were very low and only at one part of the motorway, where the exhaust gas temperature exceeds $550{ }^{\circ} \mathrm{C}$, the $\mathrm{NO}_{\mathrm{x}}$ emissions increased to $10 \mathrm{mg} / \mathrm{s}$. During dynamic driving, $\mathrm{NO}_{\mathrm{x}}$ spikes appeared during accelerations (Figure $7 \mathrm{~b}$ ). They also depended on the exhaust gas temperature and the exhaust gas flow. They were up to $15 \mathrm{mg} / \mathrm{s}$ at the rural part, but $>40 \mathrm{mg} / \mathrm{s}$ at the motorway part. They reached $90 \mathrm{mg} / \mathrm{s}$ when the exhaust gas temperature was $>600^{\circ} \mathrm{C}$.

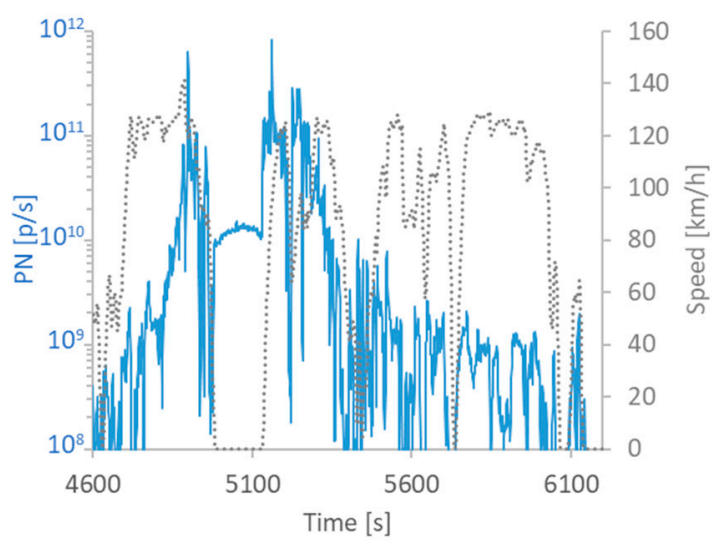

(a)

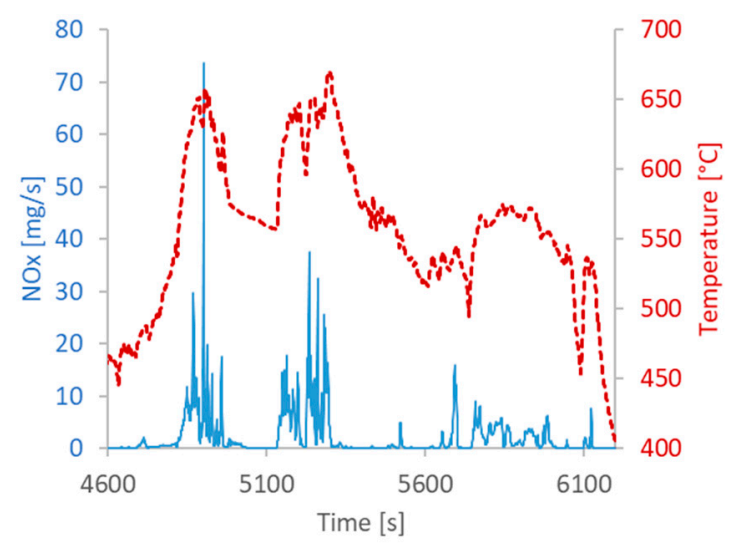

(b)

Figure 6. Emissions during the motorway part of an RDE-1-R test with regeneration: (a) Particle Number $(\mathrm{PN})>23 \mathrm{~nm}$ and speed; $(\mathbf{b}) \mathrm{NO}_{\mathrm{x}}$ and exhaust gas temperature.

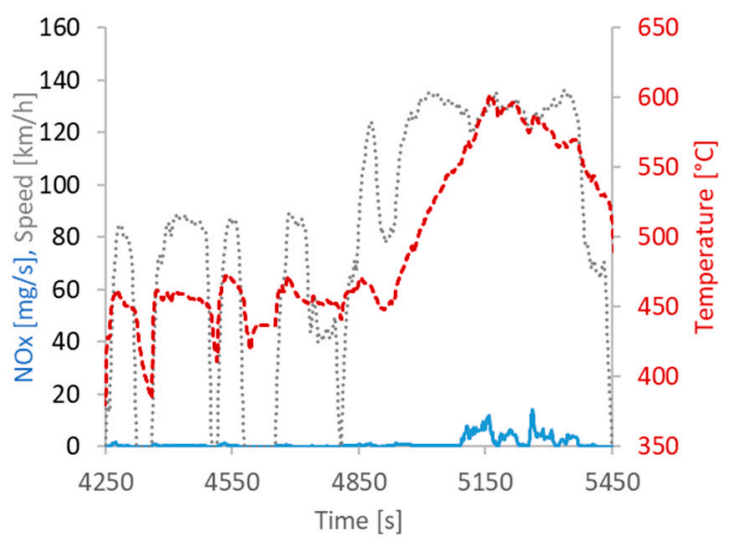

(a)

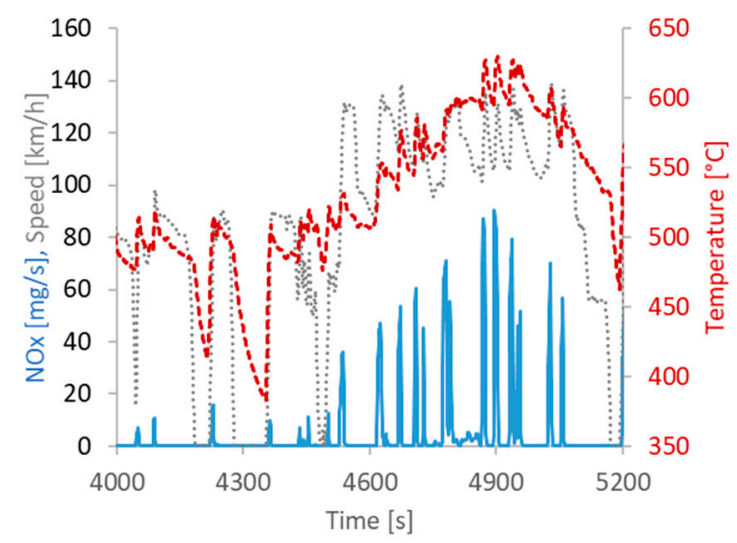

(b)

Figure 7. $\mathrm{NO}_{\mathrm{x}}$ emissions during the rural and motorway part of two RDE tests: (a) normal driving RDE-2; (b) dynamic driving RDE-2-D. 


\section{Discussion}

In this study, we measured the emissions of regulated and non-regulated pollutants of a diesel fueled vehicle both in the laboratory and on the road. For all regulated testing conditions, all currently regulated pollutants were below the applicable limits, in agreement with other studies of Euro 6d-temp diesel vehicles [45,46]. Particularly for $\mathrm{NO}_{x}$, which was the main attention topic for diesel vehicles until very recently, the emissions were below the applicable (and future) limits on the road even when DPF regeneration events occurred, and much lower compared to the pre-RDE Euro 6 diesel vehicles that were typically emitting on the road $>4$ times the limit $[23,29,54-57]$. Only dynamic driving brought the $\mathrm{NO}_{\mathrm{x}}$ levels $(200 \mathrm{mg} / \mathrm{km})$ slightly higher than the limit $(168 \mathrm{mg} / \mathrm{km}$, using the applicable 2.1 conformity factor). Others have also reported that dynamic driving significantly increases the emissions [36,46]. The $\mathrm{NO} / \mathrm{NO}_{\mathrm{x}}$ ratio was on average $78 \%$ in the laboratory tests and $65 \%$ in the on-road tests. Partly, this has to do with the different instruments used: FTIR at the laboratory, non-dispersive ultra-violet (NDUV) analyzer on the road. Differences of $5-15 \%$ between $\mathrm{NO}_{\mathrm{x}}$ measurement instruments are common [58-60]. In our case, the FTIR $\mathrm{NO}_{x}$ were on average $20 \%$ lower compared to the regulated bags methodology (Figure A3), and the PEMS 20\% higher. Possible drift of the PEMS analyzers during the long duration on-road tests could also have affected the results. For example, $1 \mathrm{ppm}$ drift in one of the NDUV analyzers (which is much lower than the 5 ppm allowed by the regulation) would change the percentages by $5 \%$. The other reason is a true difference. A closer look at the data revealed that the high NO laboratory emissions are due to the high contribution of cold start, where the catalyst is inactive in converting $\mathrm{NO}$ to $\mathrm{NO}_{2}$. Furthermore, based on the tailpipe exhaust gas measurements, the laboratory cycles had lower exhaust gas temperatures, which could mean lower engine out $\mathrm{NO}$ and lower $\mathrm{NO}$ to $\mathrm{NO}_{2}$ conversion at the oxidation catalyst [61]. On-road reported $\mathrm{NO}_{2} / \mathrm{NO}_{\mathbf{x}}$ percentages for Euro 6 vehicles with SCR around $45 \%( \pm 12 \%)$ to $54 \%( \pm 23 \%)$ [55,62], similar if only RDE-compliant cycles are considered: $56 \%( \pm 3 \%)$; but higher if all cycles are considered: $35 \%( \pm 23)$. The reason is that regenerations and dynamic driving had high $\mathrm{NO} / \mathrm{NO}_{\mathrm{x}}$ ratios.

Regarding non-regulated pollutants, distance-specific $\mathrm{NH}_{3}$ on the WLTP $23{ }^{\circ} \mathrm{C}$ test were lower than emissions on Euro 6 diesel vehicles equipped with SCR $(7-8 \mathrm{mg} / \mathrm{km})$ [46,63-65], but similar $(<1 \mathrm{mg} / \mathrm{km})$ to Euro 6 diesel vehicles retrofitted with an ammonia slip catalyst in the underfloor position $[33,46]$. Isocyanic acid (HNCO) emissions $(0.3 \mathrm{mg} / \mathrm{km})$ were similar to those reported for Euro $6 \mathrm{SCR}$-equipped diesel vehicles $(<1 \mathrm{mg} / \mathrm{km})[46,64]$, but higher at $0^{\circ} \mathrm{C}(3.5 \mathrm{mg} / \mathrm{km}) . \mathrm{N}_{2} \mathrm{O}(11-13 \mathrm{mg} / \mathrm{km})$ and $\mathrm{CH}_{4}(5-6 \mathrm{mg} / \mathrm{km})$ on the WLTP $23{ }^{\circ} \mathrm{C}$ test were in the range of emissions from diesel vehicles reported by others $[46,66]$. Two points need more discussion: emissions during cold start at different ambient temperatures, and emissions during regeneration events.

\subsection{Cold Start}

For most pollutants, the majority of the emissions were released during the first $3-4$ min of the vehicle operation, as also reported by others $[23,67]$. During cold start, defined here as the first $300 \mathrm{~s}$ of a test, the engine and aftertreatment systems of a vehicle are cold and do not function in optimal conditions [68]. As most vehicles start operating in urban environments where population density is high, cold start emissions are relevant as they make an important contribution to the increase in population exposure to air pollutants.

Figure 8 plots the cumulative $\mathrm{NO}_{\mathrm{x}}$ over the WLTCs (Figure 8a) and the two on-road Traffic routes (Figure 8 b) for various ambient temperatures.

Most of the $\mathrm{NO}_{\mathrm{x}}$ were emitted during the first $300 \mathrm{~s}$ following the first ignition of the engine. For the tests without a DPF regeneration, the share of $\mathrm{NO}_{x}$ emissions released in the first five minutes (17\% of the test time) ranged from $85 \%$ to circa $100 \%$, proving that cold start still represents a major contribution to $\mathrm{NO}_{\mathrm{x}}$ emissions for current state-of-the-art diesel vehicles. In the laboratory tests, after $300 \mathrm{~s}$, the coolant temperature reached $60^{\circ} \mathrm{C}$ when the ambient temperature was $23^{\circ} \mathrm{C}, 55^{\circ} \mathrm{C}$ at $14^{\circ} \mathrm{C}$ and $48^{\circ} \mathrm{C}$ at $0^{\circ} \mathrm{C}$. It took an additional $120 \mathrm{~s}$ to reach $60^{\circ}$ at an ambient temperature of $14^{\circ} \mathrm{C}$, and $220 \mathrm{~s}$ at $0{ }^{\circ} \mathrm{C}$. The emissions during the first $300 \mathrm{~s}$ of the WLTCs were $220-290 \mathrm{mg} / \mathrm{km}$ for the $23^{\circ} \mathrm{C}$ tests 
and $30{ }^{\circ} \mathrm{C}, 380 \mathrm{mg} / \mathrm{km}$ for the $14{ }^{\circ} \mathrm{C}$ test and $550 \mathrm{mg} / \mathrm{km}$ for the $0{ }^{\circ} \mathrm{C}$ test, proving that cold start at lower ambient temperatures results in increased $\mathrm{NO}_{\mathrm{x}}$ emissions. Different combustion and abatement strategies could explain this different $\mathrm{NO}_{x}$ emission rates occurring at different ambient temperatures. For all tests, the curves of the cumulative $\mathrm{NO}_{\mathrm{x}}$ emission flattened after circa $250 \mathrm{~s}\left(300 \mathrm{~s}\right.$ for the $0{ }^{\circ} \mathrm{C}$ test) when the SCR catalyst started effectively reducing $\mathrm{NO}_{\mathrm{x}}$ emissions. A detailed presentation of regulated and non-regulated pollutant emission during the cold start as compared to the complete WLTC is given in the Appendix A (Figure A4).

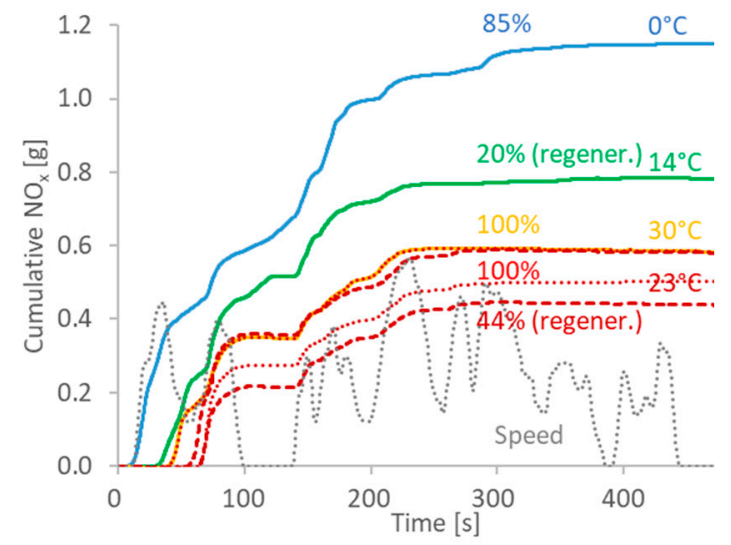

(a)

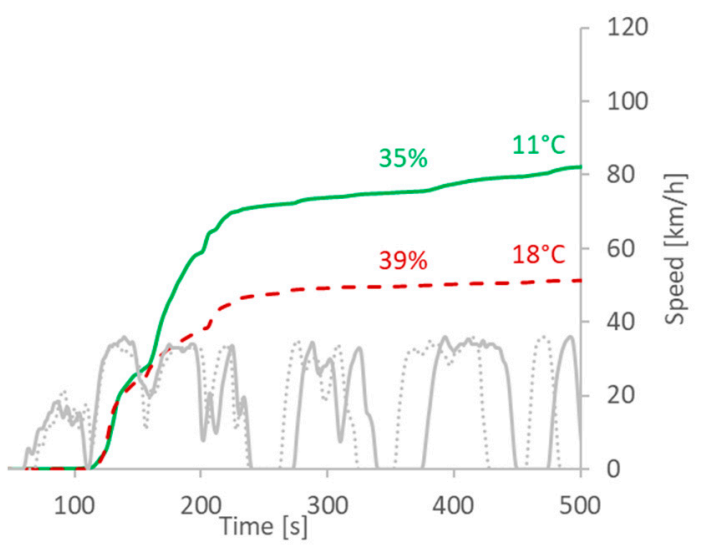

(b)

Figure 8. Cumulative $\mathrm{NO}_{\mathrm{x}}$ emissions at various ambient temperatures: (a) laboratory WLTCs; (b) on-road Traffic routes. Percentages give the ratio of cumulative $\mathrm{NO}_{\mathrm{x}}$ after $300 \mathrm{~s}$ to the total $\mathrm{NO}_{\mathrm{x}}$ at the end of the test. In brackets is mentioned if a regeneration event took place at the high speed part of the cycle. WLTC $=$ Worldwide Light-duty Test Cycle.

Despite the natural variability of on-road testing, the two Traffic tests were performed with similar settings (same driver, same route, soak ambient temperature circa $18{ }^{\circ} \mathrm{C}$ ) and emissions at cold start are compared for illustration purposes, as the first test took place in the morning at an ambient temperature that was circa $10{ }^{\circ} \mathrm{C}$ lower than the second test performed in the evening. While the emissions at the beginning of the routes were similar, at around $150 \mathrm{~s}$ they started to deviate. The different ambient temperatures sensed by the vehicle probably changed the EGR operation and consequently the emissions, as reported by others [23]. The results are in good agreement with the laboratory tests with similar behavior. The cold start contribution ranged between $35 \%$ and $39 \%$ of the total $\mathrm{NO}_{\mathrm{x}}$, which is sensibly lower than for the laboratory tests without regeneration. This can be explained by the higher dynamicity in the Traffic tests as compared to the WLTC (Figure A2) and the lower share of cold start with respect to the duration of the test $(<10 \%)$, as the Traffic test lasted $53 \mathrm{~min}$ (Table 1).

Figure 9 displays the cumulative PN emissions over the WLTCs (Figure 9a) and the two on-road Traffic routes (Figure 9b) for various ambient temperatures. Almost all of the particles are emitted in the first 100-150 s of the cold start, both in the laboratory tests and on the Traffic on-road tests. In particular, most of the $\mathrm{PN}$ is released with the ignition of the engine and in the first acceleration of the vehicle (first $50 \mathrm{~s}$ from ignition) [69]. As for the case of $\mathrm{NO}_{x}$, during cold start, $\mathrm{PN}$ emissions are higher in tests performed at lower ambient temperatures. The cold start spikes for DPF-equipped vehicles are well known. On the one hand, the engine out emissions are higher, and, on the other hand, the DPF has reduced efficiency due to defects in the mat employed to mount the brick in the canister [70]. As the DPF heats up, the defects close. The effect is more pronounced at lower temperatures which require a longer time, especially for the mounting material being in direct contact with the canister. The cold start contribution to the total PN is higher in the laboratory tests than on the road for the 
same reasons as for $\mathrm{NO}_{\mathrm{x}}$ (lower share of cold start with respect to the total duration of the Traffic tests, and higher dynamicity).

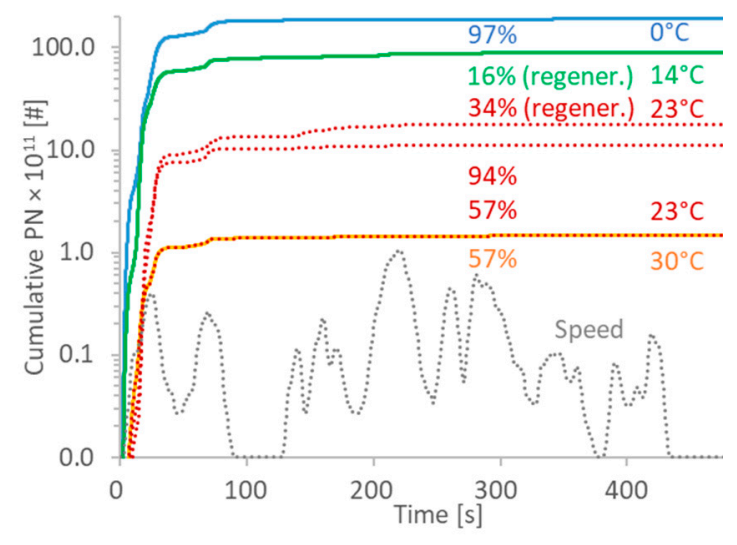

(a)

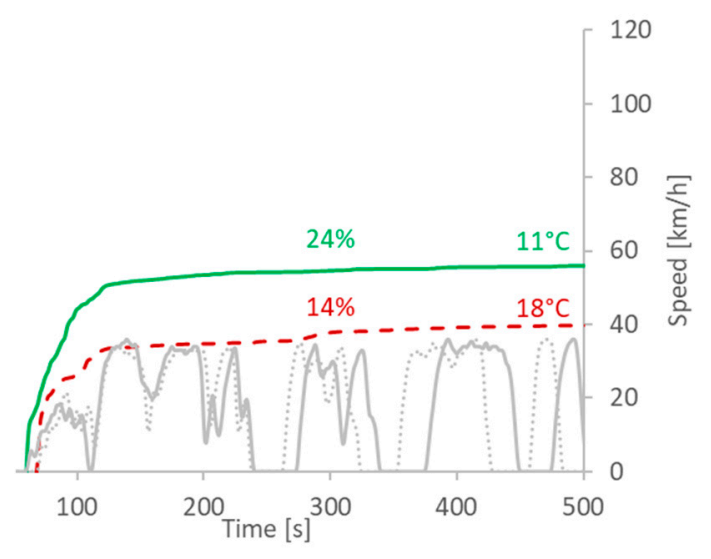

(b)

Figure 9. Cumulative Particle Number $(\mathrm{PN})$ emissions $(>23 \mathrm{~nm})$ at various ambient temperatures: (a) laboratory WLTCs; (b) on-road Traffic routes. Percentages give the ratio of cumulative PN after $300 \mathrm{~s}$ to the total PN at the end of the test. In brackets is mentioned if a regeneration event took place at the high speed part of the cycle. WLTC $=$ Worldwide Light-duty Test Cycle.

\subsection{Regeneration}

One unique characteristic of this study is that the car was driven approximately $1300 \mathrm{~km}(900 \mathrm{~km}$ on the road and $400 \mathrm{~km}$ in the laboratory) in order to capture many regenerations and have a more complete picture of the emissions, i.e., including the regenerations.

\subsubsection{Regeneration Frequency}

Figure 10 summarizes the regeneration frequency as identified in this study and values reported in the literature [38,40,70-77]. For Euro 5 vehicles, the mean distance was around $495 \mathrm{~km}( \pm 215 \mathrm{~km})$, while for Euro 6, around $415 \mathrm{~km}( \pm 155 \mathrm{~km})$. In this study, the distance between regenerations varied from $60 \mathrm{~km}$ to $360 \mathrm{~km}$, with a mean of $196 \mathrm{~km}( \pm 110 \mathrm{~km})$. The $60 \mathrm{~km}$ distance could be explained by the incomplete previous regeneration, which did not completely empty the DPF. This is the first study, according to our knowledge, in which such short distances have been reported. It is also important to note that the scatter around the mean was high. Such high scatter has also been reported in one more study [75].

Active/forced regenerations are not only triggered when a specific distance (or time) has been accumulated since the last regeneration event, but other parameters such as engine back pressure, and/or estimated accumulated soot play an important role [78]. Thus, the driving style and the ambient temperature are important. Furthermore, sometimes regenerations are not triggered for cleaning the filter, but for resetting the system to a known state or desulfation of catalysts. Thus, the high scatter is understandable due to the big variety of driving conditions and/or different strategies of the different vehicle manufacturers. As there is no information regarding the DPFs, it is not possible to explain why the distance between regenerations has decreased. Nevertheless, one reason could be that DPFs have been increasingly replaced by SCR-coated DPFs, which have reduced passive regeneration due to ammonia dosing and the competition for $\mathrm{NO}_{2}$ between soot and SCR reactions [79], and consequently, more active regenerations are needed. 


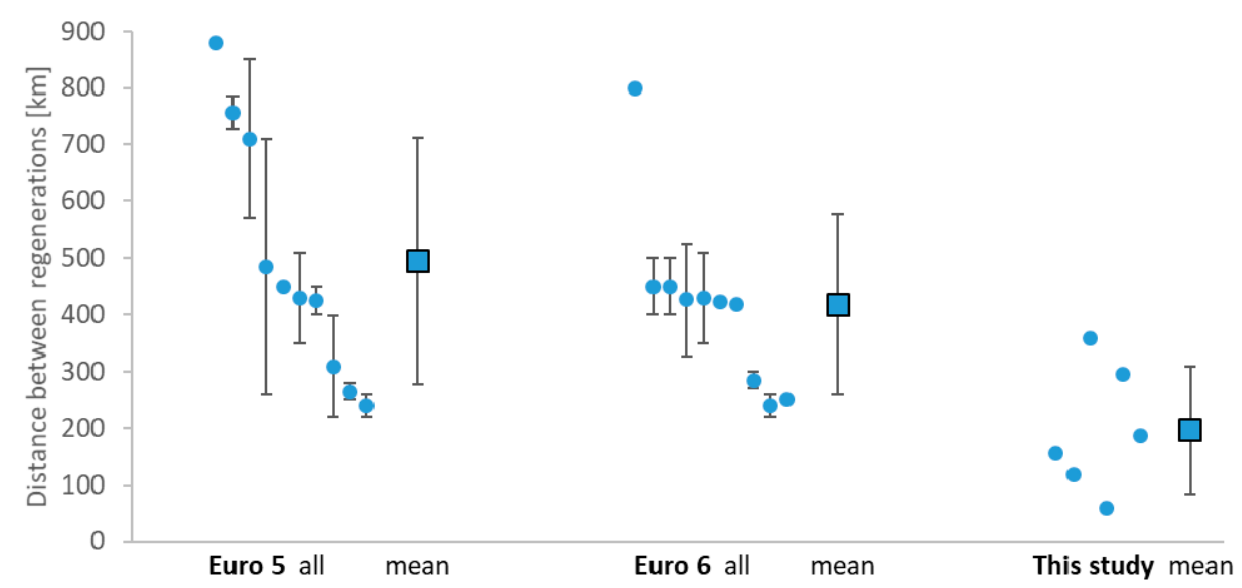

Figure 10. Distances between regeneration events of light-duty vehicles based on this study and the literature (details in text). Literature data are in descending order. The data of this study are in chronological order.

There are a few implications of the frequent regenerations:

1. Do the emissions exceed the limits and, if yes, how much?

2. In which driving conditions do the regeneration events take place?

3. Do the weighted emissions, including regeneration events, still respect the limits?

Regarding the first point, it was shown that the laboratory limits can be exceeded in some cases. The PN emissions exceeded the limit by $300 \%$ at the regenerating WLTC cycle at $14{ }^{\circ} \mathrm{C}$, but were only $40 \%$ of the emission limit at the regenerating WLTC cycle at $23^{\circ} \mathrm{C}$. The PN on-road tests were below the NTE limit even when regenerations took place (four cases). For $\mathrm{NO}_{x}$, the emissions were exceeded only at the regenerating WLTC cycle at $14^{\circ} \mathrm{C}$, by a factor of 2 . At all other tests in the lab or on the road, the emissions were below the applicable limits. Since there are cases where the limits are exceeded, one question is where do the regeneration events take place (i.e., which driving conditions are compatible with a regeneration event). In the laboratory, both regeneration events took place at the high speed part of the cycle, which corresponds to a typical motorway drive. On the road, from the four regeneration events, two took place after the motorway part, entering the city or the rural section, while the other two took place at the high speed part of the routes. The rural/urban regenerations $(1.5-3.5 \mathrm{~km})$ emitted $0.4-1.5 \times 10^{13}$ particles, while the motorway $(12-24 \mathrm{~km}), 1.3-2.5 \times 10^{13}$ particles. In the laboratory, the regenerations $(5.8-8.8 \mathrm{~km})$ emitted $0.2-5.0 \times 10^{13}$ particles. Such levels have also been reported by others $[38,70,73]$. DPF regenerations tend to occur at high speed, although in one out of the six registered events, the regenerations took place in the city while the vehicle was being driven at slow speeds in stop and go traffic conditions, which is a relevant issue as human exposure may be large.

In order to assess the contribution of regeneration events to the emission levels, the emitted particles of the regenerating cycles were added to the sum of particles of the non-regenerating cycles (Figure 11). The sum of particles was divided by the total driven distance. This procedure was done for all tests in the laboratory (Overall lab in Figure 11a), for all tests on the road (Overall RDE*) and for all tests both in the lab and on the road (Overall). The (weighted) PN emissions were below the applicable limits in the lab or on the road by a factor of 2 and 9, respectively. The inclusion of the sub-23 $\mathrm{nm}$ particles did not change the picture, as the emissions remained below the PN limit. 


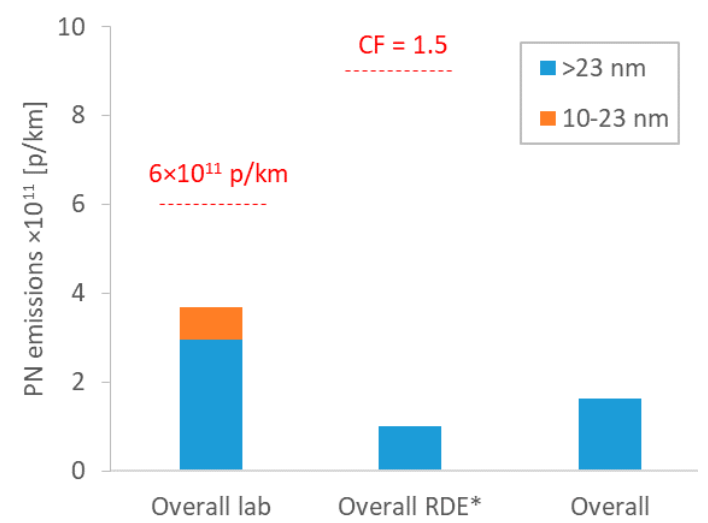

(a)

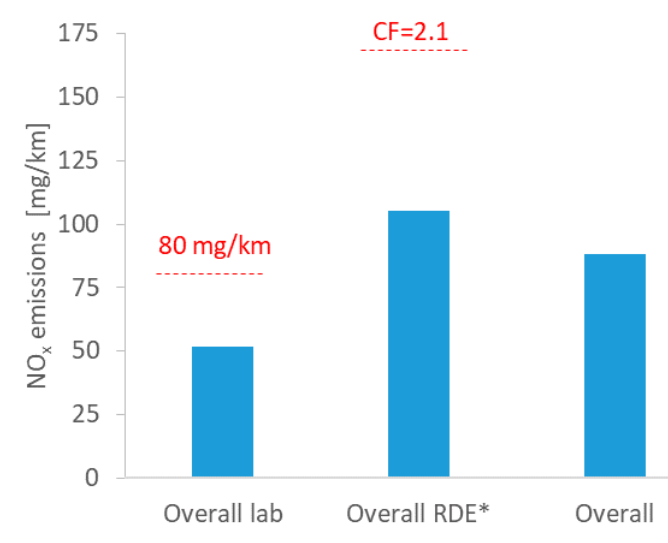

(b)

Figure 11. Weighted emissions (including regenerations): (a) Particle Number (PN); (b) $\mathrm{NO}_{\mathrm{x}}$. $\mathrm{RDE}^{*}$ refers to a mix of Real-Driving Emissions (RDE)-compliant and non-compliant routes.

The same procedure was followed for $\mathrm{NO}_{x}$ (Figure 11b). The (weighted) laboratory emissions were $50 \mathrm{mg} / \mathrm{km}$, below the $80 \mathrm{mg} / \mathrm{km}$ limit. The on-road $\mathrm{NO}_{x}$ emissions were $105 \mathrm{mg} / \mathrm{km}$, also below the $168 \mathrm{mg} / \mathrm{km}(\mathrm{CF}=2.1)$ applicable limit for this car or the future limit of $114 \mathrm{mg} / \mathrm{km}(\mathrm{CF}=1.43)$.

It should be emphasized that the inclusion of the regeneration emissions is applicable for $\mathrm{NO}_{\mathrm{x}}$ in the lab (not for PN). Our tests showed that the same approach could be applied to PN as well. For $\mathrm{RDE}$ tests, a test with regeneration can be repeated, but if a regeneration occurs at the second test, then the limit has to be respected for both $\mathrm{NO}_{\mathrm{x}}$ and $\mathrm{PN}$.

\subsubsection{PN Instrumentation}

Figure 12 plots the PN emissions during the WLTC at $14{ }^{\circ} \mathrm{C}$ with regeneration. In the first two minutes of the cycle there is a spike of particles, and the $10-23 \mathrm{~nm}$ particles are $28 \%$ higher than the $23 \mathrm{~nm}$. The higher sub-23 nm fraction during the first two minutes has also been reported by others $[41,80,81]$. During regeneration (i.e., time after $1350 \mathrm{~s}$ ) there is an increase in particles at the levels of cold start, but there is no difference between the $>23$ and $>10 \mathrm{~nm}$ concentrations, indicating that they consist mainly of soot particles (mean diameter $>50 \mathrm{~nm}$ ) [82]. There is, however, a high difference at the end of the regeneration (time $1650 \mathrm{~s}$ ). This has sometimes been seen by others as well $[70,83]$. This difference has been attributed many times to volatile re-nucleation downstream of the evaporation tube (volatile artefact) [84]. Recently, it was also suggested that these sub-23 nm particles are non-volatile in nature as their concentration did not change with different dilutions or using catalytic stripper [85]. Elastomer connectors, which was not the case at our tests, can release non-volatile particles at elevated temperatures [86]. Another possibility is that these particles consist of compounds with boiling points around $350{ }^{\circ} \mathrm{C}$, which is the temperature of the evaporation tube of the PN system. It is suspected that a source of such compounds is the transfer line between the vehicle and the dilution tunnel [87]. The contribution of volatile material is indirectly supported by the mass measurements. Even though we used one filter for the whole campaign to minimize volatile artifacts on the filter, the PN/PM ratio was $3.8-4.8 \times 10^{11} \mathrm{p} / \mathrm{mg}$, lower than the typically expected $1-2 \times 10^{12} \mathrm{p} / \mathrm{mg}$, indicating that the contribution of volatiles was significant. We suspect that the origin is released material from the transfer tube to the dilution tunnel during the high exhaust gas temperature regeneration events [88]. 


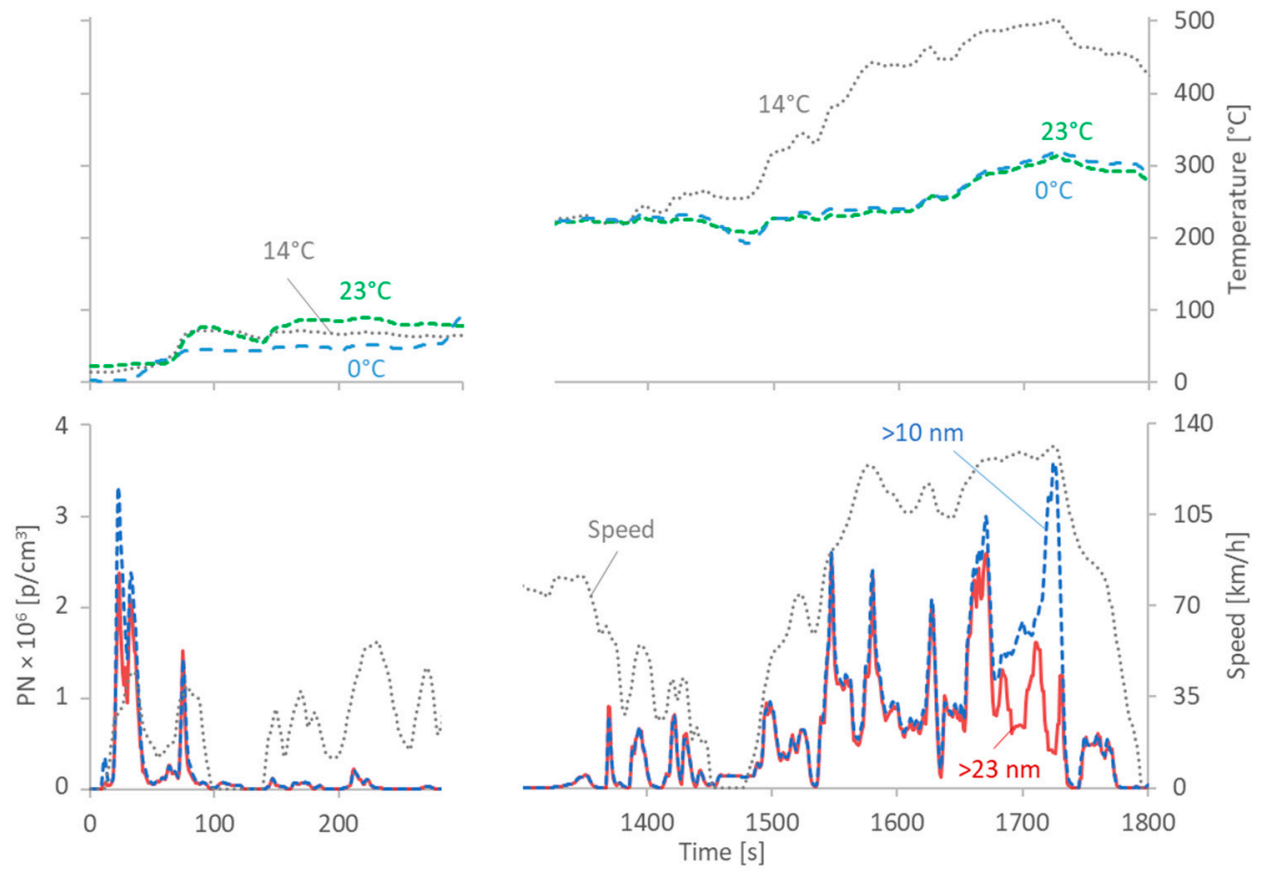

Figure 12. Particle number (PN) emissions $>23 \mathrm{~nm}$ and $>10 \mathrm{~nm}$ for the WLTC at $14{ }^{\circ} \mathrm{C}$ with regeneration (lower panel). The exhaust gas temperature as measured at the tailpipe is also plotted for the specific test at $14{ }^{\circ} \mathrm{C}$, and two others at $0{ }^{\circ} \mathrm{C}$ and $23^{\circ} \mathrm{C}$ (upper panel). Note that the $\mathrm{x}$ axis is split to present the cold start section, and the section when the DPF (Diesel Particulate Filter) regeneration takes place. WLTC $=$ Worldwide Light-duty Test Cycle.

\subsubsection{Fuel Penalty}

Regarding the fuel penalty due to regeneration, comparison of the WLTCs at $23{ }^{\circ} \mathrm{C}$ with and without regeneration gave a $4 \%$ difference. For comparison, the test at $0{ }^{\circ} \mathrm{C}$ had $11 \%$ higher $\mathrm{CO}_{2}$ than at $23{ }^{\circ} \mathrm{C}$. For the on-road trips, the regeneration effect was $<1 \%$, which is much less than the effect of dynamic driving, which was between $6.7 \%$ and $9.1 \%$.

\section{Conclusions}

In this study, we measured the emissions of a Euro 6d-temp vehicle driven more than $400 \mathrm{~km}$ in the laboratory and $900 \mathrm{~km}$ on the road, at ambient temperatures between $0{ }^{\circ} \mathrm{C}$ and $30^{\circ} \mathrm{C}$. During the testing, six DPF regenerations took place (two in the laboratory). The vehicle respected all applicable emission limits, both in the laboratory and on the road (WLTP $23^{\circ} \mathrm{C}$ and RDE-compliant tests). The PN limit was exceeded only during a cold start test at $0{ }^{\circ} \mathrm{C}(+40 \%)$, and during a regeneration at $14{ }^{\circ} \mathrm{C}$, by a factor of 4 . The $\mathrm{NO}_{\mathrm{x}}$ limit of $80 \mathrm{mg} / \mathrm{km}$ was exceeded only during one of the two laboratory regeneration events by a factor of two, and during dynamic driving on the road (reaching up to $200 \mathrm{mg} / \mathrm{km}$ ). The $\mathrm{NO}$ to $\mathrm{NO}_{\mathrm{x}}$ ratio was, in most cases, around $70 \%$ to $90 \%$, but lower values $(45 \%$ to $85 \%$ ) were measured during the on-road tests. The difference was attributed to the high contribution of cold start in the laboratory tests, where the $\mathrm{NO}_{\mathrm{x}}$ emissions consisted mainly of $\mathrm{NO}$. As compared to the complete WLTC, cold start emissions (first $300 \mathrm{~s}$ of the WLTC) increased by a factor of 10 for PN, and 7-8 for $\mathrm{NO}_{\mathrm{x}}$ and $\mathrm{CH}_{4}$. Over WLTC, practically, the majority (>85\%) of $\mathrm{NO}_{\mathrm{x}}$ and $\mathrm{PN}$ were emitted during the first $300 \mathrm{~s}$, whereas on the road, where the tests last longer, the contribution of the cold start was less relevant.

Regarding non regulated pollutants, ammonia was always at the instrument (FTIR) background levels $(<1 \mathrm{ppm})$, except during regenerations in which up to $8 \mathrm{ppm}$ were measured $(1 \mathrm{mg} / \mathrm{km}) . \mathrm{N}_{2} \mathrm{O}$ was around $11 \mathrm{mg} / \mathrm{km}$, and reached $13.5 \mathrm{mg} / \mathrm{km}$ during a cycle with regeneration. $\mathrm{CH}_{4}$ was around $6 \mathrm{mg} / \mathrm{km}$. $\mathrm{N}_{2} \mathrm{O}$ and $\mathrm{CH}_{4}$ accounted for $1 \%$ of the $\mathrm{CO}_{2}$-equivalent emissions of this vehicle. Isocyanic acid (HNCO) 
emissions reached $3.5 \mathrm{mg} / \mathrm{km}$ in the $0{ }^{\circ} \mathrm{C}$ test. The rest of the pollutants, such as formaldehyde and acetaldehyde, were at background levels, even during regeneration events. The fraction of particles below $23 \mathrm{~nm}$, the lowest size limit defined in the current regulation, was $11-51 \%$, with the highest percentage at the lowest absolute levels.

One important finding of study was the high frequency of regeneration events: on average, it was every $196 \mathrm{~km}$. This frequency is much lower compared to the mean of Euro 5 vehicles $(495 \mathrm{~km})$ and Euro 6 vehicles $(415 \mathrm{~km})$ found searching the literature. Such frequent regenerations need to be considered when emissions from diesel vehicles are reported. Nevertheless, the emissions, weighted also for the regenerations, were below the applicable limits; the absolute levels were two times (for $\mathrm{NO}_{\mathrm{x}}$ ) to four times (for PN) lower than the type approval values. In one case, the regeneration took place in the urban part, which is relevant as human exposure is increased due to population density. Our tests showed that the methodology to include the regeneration emissions in the weighted result, applicable to $\mathrm{NO}_{\mathrm{x}}$, could also be applied to $\mathrm{PN}>23 \mathrm{~nm}$. An interesting finding, though, was that during one regeneration event, the sub- $23 \mathrm{~nm}$ fraction of solid particles increased (23\%). These seem to be artefact particles, probably due to the high exhaust gas temperature of the regeneration event. Thus, more research will be needed in that direction when the future $>10 \mathrm{~nm}$ regulation is in place. The reported emissions correspond to a vehicle with low mileage ( $3000 \mathrm{~km}$ at the start of the campaign), and further investigation needs to confirm that similar environmental performance is maintained during the vehicle's lifetime.

Author Contributions: Conceptualization, B.G.; methodology, V.V.; formal analysis, V.V. and B.G.; writing - original draft preparation, V.V. and B.G. All authors have read and agreed to the published version of the manuscript.

Funding: This research received no external funding.

Acknowledgments: The authors acknowledge the technical support of the RDE team P. Canevari, J. Franzetti, and R. Quarto, and the VELA staff C. Bonato, C. Ferrarese, A. Migneco, M. Sculati. Special acknowledgments to P. Bonnel for his valuable comments at an earlier draft version.

Conflicts of Interest: The authors declare no conflict of interest.

Disclaimer: The opinions expressed in this manuscript are those of the authors and should in no way be considered to represent an official opinion of the European Commission. Mention of trade names or commercial products does not constitute endorsement or recommendation by the European Commission or the authors.

\section{Appendix A}

Figure A1 presents the vehicle speed and altitude profiles of the routes used in the test campaign. For the routes that were driven more than once, a test-to-test variability in the speed profile can expected due to the stochastic nature of the on-road testing. The tests driven dynamically over routes RDE-1 and RDE-2 share the altitude profile of those routes.

The driving dynamics of the on-road tests, expressed as velocity times positive acceleration per phase (Urban/Rural/Motorway) and for the WLTC phases (Low/Medium/High/Extra high) are plotted in Figure A2.

Figure A3 presents a comparison of emissions as measured in the bag and with the FTIR for the six laboratory tests presented in Section 2.2, and three additional preconditioning cycles performed prior to the $23^{\circ} \mathrm{C}$ tests.

The results are presented for the complete WLTC tests as well as for the WLTC phases (Low, Medium, High, and Extra-high) for $\mathrm{CO}_{2}, \mathrm{NO}_{\mathrm{x}}$ and $\mathrm{CH}_{4}$. The correlation between the two measurement methods is good over the measured emission ranges, with $\mathrm{R}^{2}$ being 0.90 to 0.99 . The FTIR accuracy for $\mathrm{CO}_{2}$ and $\mathrm{CH}_{4}$ is good as compared to the bag measurement, whereas a $20 \%$ underestimation of $\mathrm{NO}_{x}$ is observed. 

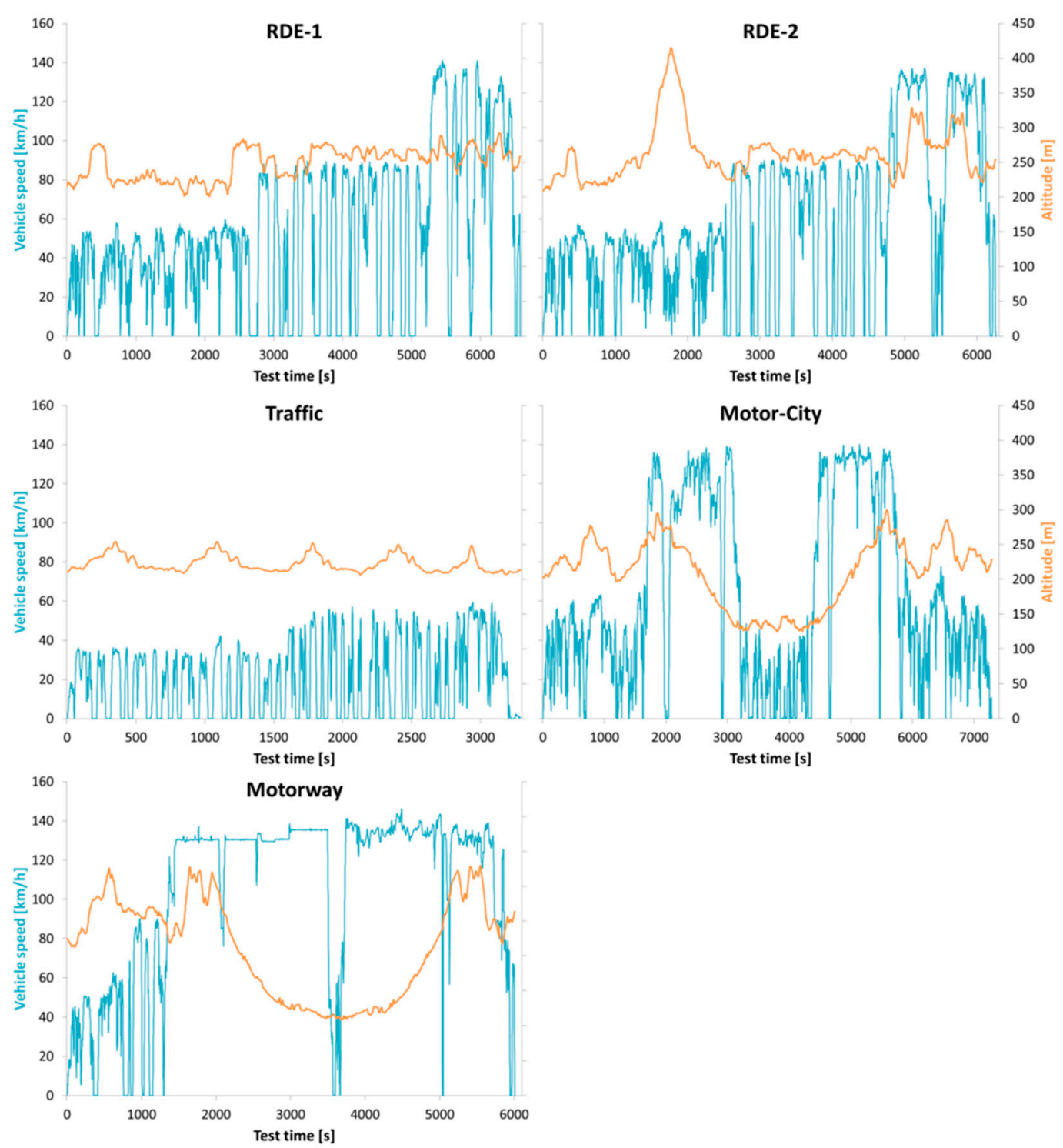

Figure A1. Vehicle speed $[\mathrm{km} / \mathrm{h}]$ and altitude $[\mathrm{m}]$ profiles as measured with the GPS (Global Positioning System) of the PEMS (Portable Emissions Measurement System) of the routes used in the test campaign.

Figure A4 presents an overview of cold start emissions of a selection of air pollutants and greenhouse gases as measured with the $23 \mathrm{~nm}$ particle counter (PN) and FTIR (gases) in the laboratory at different ambient temperatures. On the WLTC, $300 \mathrm{~s}$ corresponds to a distance of $2 \mathrm{~km}$ driven at an average speed of $24.3 \mathrm{~km} / \mathrm{h}$, including a stop of $30 \mathrm{~s}$. The WLTC Low phase, which characterizes urban driving, lasts $589 \mathrm{~s}$ over a distance of $3.1 \mathrm{~km}$ and an average speed of $18.9 \mathrm{~km} / \mathrm{h}$, including stops. In general, distance-specific emissions are higher at cold start and WLTC Low than they are over the complete WLTC on all tested ambient temperatures. For example, cold start PN distance-specific emissions are circa ten times higher than they are over the complete cycle on all tested temperatures. Cold start $\mathrm{NO}_{\mathrm{x}}$ is 7-8 times higher than it is over the complete WLTC. The highest $\mathrm{PN}$ and $\mathrm{NO}_{\mathrm{x}}$ emissions occur at the lowest ambient temperature $\left(0{ }^{\circ} \mathrm{C}\right)$ reaching $9 \times 10^{12} \mathrm{p} / \mathrm{km}$ and $487 \mathrm{mg} / \mathrm{km}$, respectively, at cold start. $\mathrm{NH}_{3}$ emissions are equivalent at cold start, WLTC Low, and complete WLTC, and emissions are higher at $30^{\circ} \mathrm{C}$ than at other ambient temperatures. The distance-specific emissions of $\mathrm{CO}_{2}$ and $\mathrm{N}_{2} \mathrm{O}$ are $30 \%$ higher at cold start than over the complete WLTC at $23{ }^{\circ} \mathrm{C}$, whereas the increase for $\mathrm{CH}_{4}$ is more significant (8.5 times higher). 


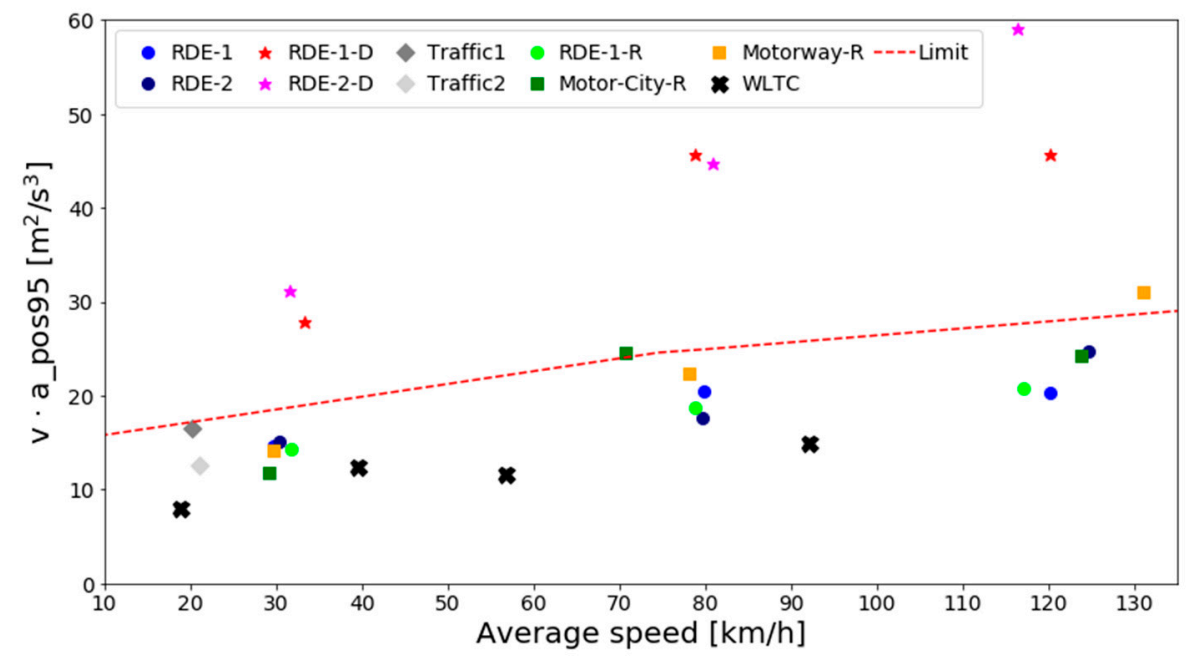

Figure A2. Overview of the driving dynamics, in terms of the 95th percentile of $v \times a$ for the laboratory and RDE tests. There are three markers per RDE test corresponding to the respective Urban/Rural/Motorway phase. Note that the Traffic tests are Urban-only tests. Tests labelled with an $\mathrm{R}$ at the end correspond to those where a DPF regeneration occurred. The red dotted line indicates the 95th percentile of the $v \times a$ limit, as defined for M1 vehicles in Appendix 7 of the RDE regulation. The WLTC laboratory cycle is divided into its respective phases. RDE = Real-Driving Emissions; WLTC $=$ Worldwide harmonized Light vehicles Test Cycle .
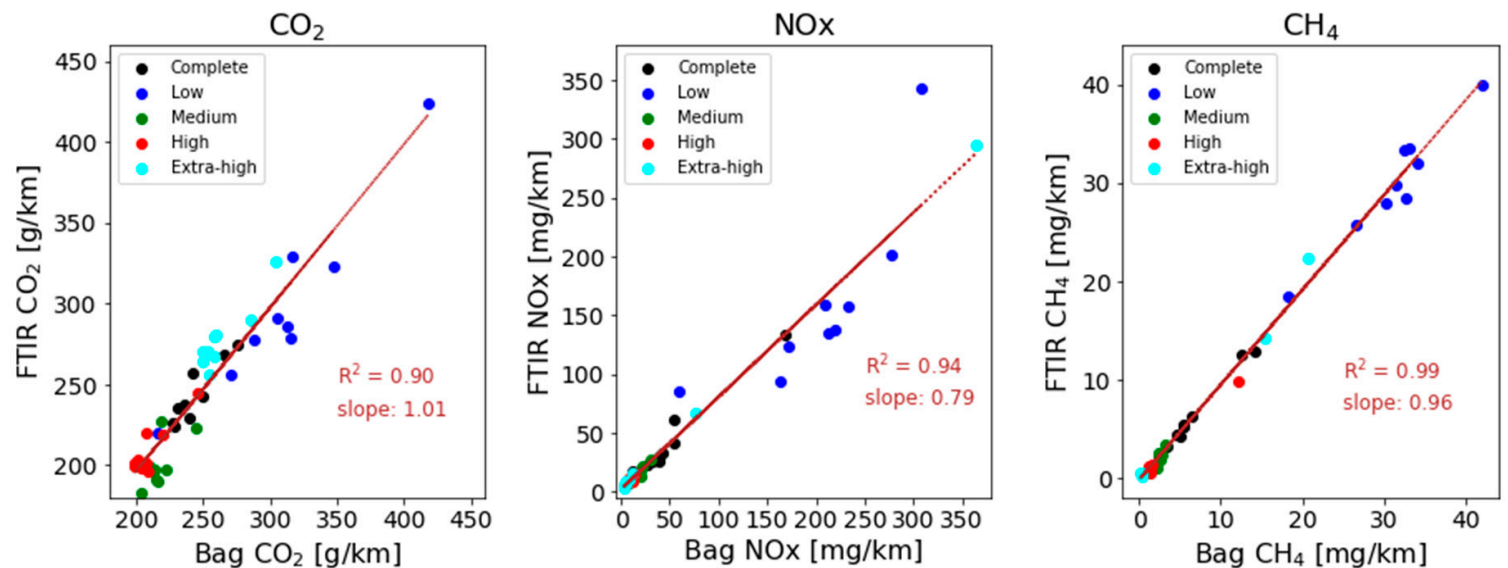

Figure A3. Scatterplot of Bag vs. FTIR distance-specific emissions for $\mathrm{CO}_{2}, \mathrm{NO}_{\mathrm{x}}$ and $\mathrm{CH}_{4}$ for the complete laboratory WLTC tests and their respective sub-phases. Number of tests considered: 9. The brown dotted line represents the fitted line to the scatter data of each pollutant, considering all cycles and sub-phases. 


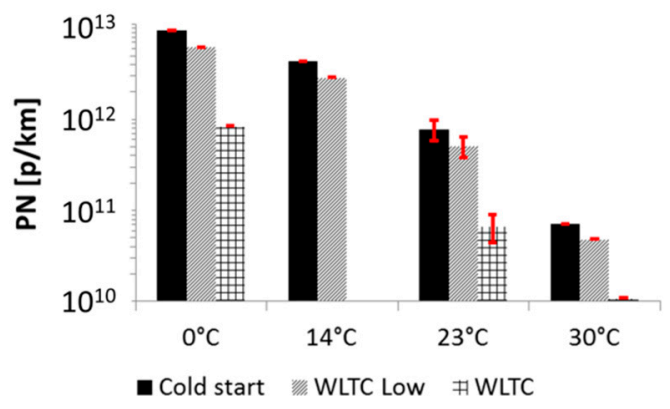

(a)

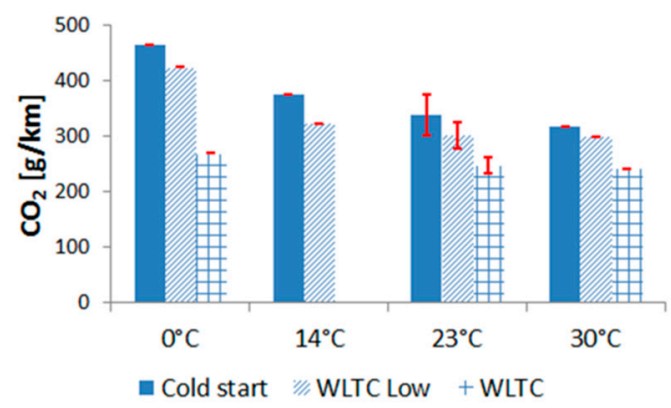

(c)

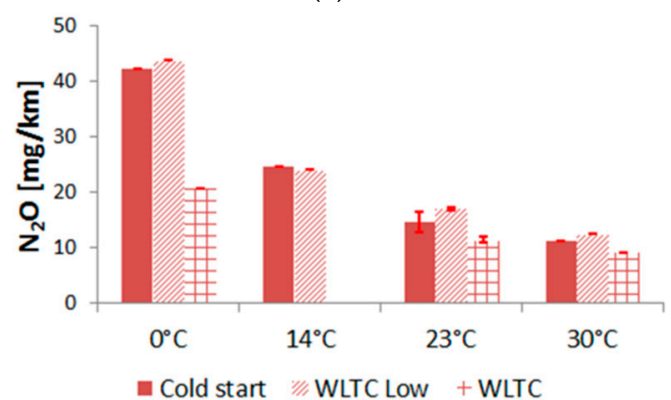

(e)

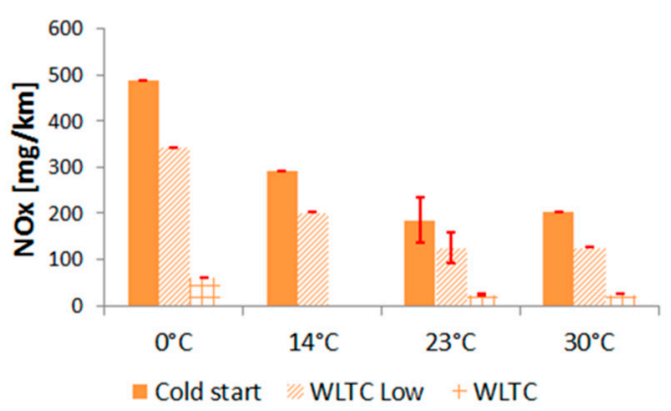

(b)

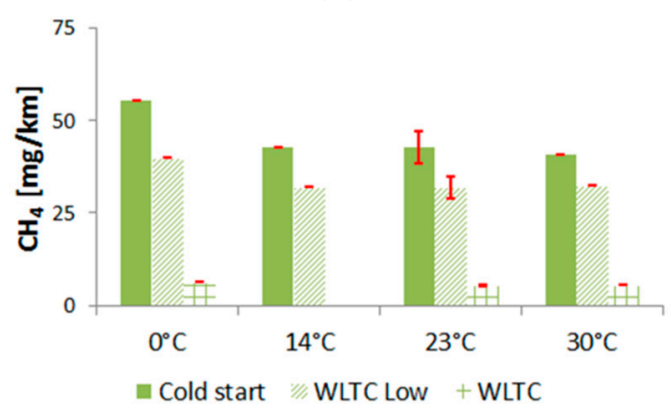

(d)

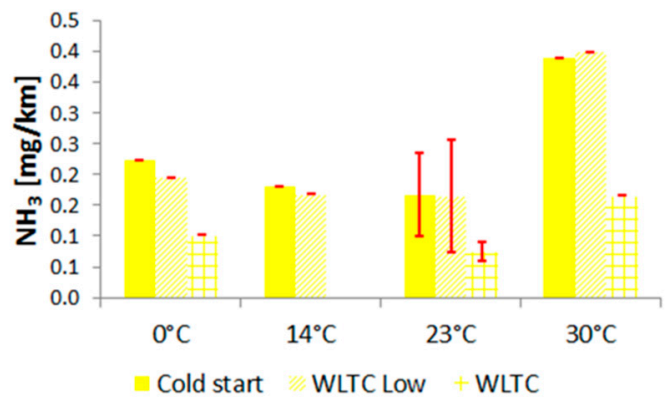

(f)

Figure A4. Emissions of PN [p/km] (a), $\mathrm{NO}_{\mathrm{x}}[\mathrm{mg} / \mathrm{km}](\mathbf{b}), \mathrm{CO}_{2}[\mathrm{mg} / \mathrm{km}](\mathbf{c}), \mathrm{CH}_{4}[\mathrm{mg} / \mathrm{km}](\mathbf{d}), \mathrm{N}_{2} \mathrm{O}$ $[\mathrm{mg} / \mathrm{km}](\mathbf{e})$, and $\mathrm{NH}_{3}[\mathrm{mg} / \mathrm{km}]$ (f) at cold start (first $300 \mathrm{~s}$ of the cycle), WLTC Low phase, and complete WLTC, at different laboratory ambient temperatures. The error bars represent the standard deviation. Particle Number (PN) emission as measured with the $23 \mathrm{~nm}$ particle counter and gas emissions as measured from the FTIR (Fourier Transform Infrared Spectrometer). WLTC = Worldwide Light-duty Test Cycle.

Table A1. Distance-specific emissions of regulated and non-regulated pollutants over the WLTC (Worldwide Light-duty Test Cycle), as measured with FTIR (Fourier Transform Infrared Spectrometer) from the tailpipe at different ambient temperatures.

\begin{tabular}{|c|c|c|c|c|c|c|c|c|}
\hline WLTC & $\begin{array}{l}\mathrm{CO}_{2} \\
\mathrm{~g} / \mathrm{km}\end{array}$ & $\underset{\mathrm{mg} / \mathrm{km}}{\mathrm{CO}}$ & $\begin{array}{c}\mathrm{NO}_{x} \\
\mathrm{mg} / \mathrm{km}\end{array}$ & $\underset{\mathrm{mg} / \mathrm{km}}{\mathrm{CH}_{4}}$ & $\begin{array}{c}\mathrm{N}_{2} \mathrm{O} \\
\mathrm{mg} / \mathrm{km}\end{array}$ & $\begin{array}{c}\mathrm{NH}_{3} \\
\mathrm{mg} / \mathrm{km}\end{array}$ & $\begin{array}{l}\mathrm{HCHO} \\
\mathrm{mg} / \mathrm{km}\end{array}$ & $\begin{array}{c}\mathrm{CH}_{3} \mathrm{CHO} \\
\mathrm{mg} / \mathrm{km}\end{array}$ \\
\hline $0^{\circ} \mathrm{C}$ & 268.9 & 61.8 & 61.0 & 6.3 & 20.7 & 0.1 & 3.4 & 21.2 \\
\hline $14^{\circ} \mathrm{C} \operatorname{Reg}$ & 274.5 & 41.2 & 134.0 & 12.8 & 13.7 & 1.0 & 1.8 & 19.1 \\
\hline $23^{\circ} \mathrm{C}$ & 242.3 & 10.4 & 24.6 & 5.4 & 11.4 & 0.1 & 0.3 & 18.7 \\
\hline $23^{\circ} \mathrm{C}$ Reg. & 247.3 & 12.5 & 40.9 & 12.4 & 12.4 & 0.9 & 0.6 & 19.1 \\
\hline $30^{\circ} \mathrm{C}$ & 240.7 & 4.8 & 24.9 & 5.6 & 9.1 & 0.2 & 0.4 & 21.7 \\
\hline
\end{tabular}




\section{References}

1. Ochoa-Hueso, R.; Munzi, S.; Alonso, R.; Arróniz-Crespo, M.; Avila, A.; Bermejo, V.; Bobbink, R.; Branquinho, C.; Concostrina-Zubiri, L.; Cruz, C.; et al. Ecological impacts of atmospheric pollution and interactions with climate change in terrestrial ecosystems of the Mediterranean Basin: Current research and future directions. Environ. Pollut. 2017, 227, 194-206. [CrossRef] [PubMed]

2. Xie, Y.; Dai, H.; Dong, H.; Hanaoka, T.; Masui, T. Economic impacts from PM2.5 pollution-related health effects in China: A provincial-level analysis. Environ. Sci. Technol. 2016, 50, 4836-4843. [CrossRef] [PubMed]

3. Brunekreef, B.; Holgate, S.T. Air pollution and health. Lancet 2002, 360, 1233-1242. [CrossRef]

4. Guarnieri, M.; Balmes, J.R. Outdoor air pollution and asthma. Lancet 2014, 383, 1581-1592. [CrossRef]

5. Hoek, G.; Krishnan, R.M.; Beelen, R.; Peters, A.; Ostro, B.; Brunekreef, B.; Kaufman, J.D. Long-term air pollution exposure and cardio-respiratory mortality: A review. Environ. Health 2013, 12, 43. [CrossRef]

6. Bai, L.; Chen, H.; Hatzopoulou, M.; Jerrett, M.; Kwong, J.C.; Burnett, R.T.; van Donkelaar, A.; Copes, R.; Martin, R.V.; Van Ryswyk, K.; et al. Exposure to ambient ultrafine particles and nitrogen dioxide and incident hypertension and diabetes. Epidemiology 2018, 29, 323-332. [CrossRef]

7. Loomis, D.; Grosse, Y.; Lauby-Secretan, B.; Ghissassi, F.E.; Bouvard, V.; Benbrahim-Tallaa, L.; Guha, N.; Baan, R.; Mattock, H.; Straif, K. The carcinogenicity of outdoor air pollution. Lancet Oncol. 2013, 14, 1262-1263. [CrossRef]

8. Wu, X.; Nethery, R.C.; Sabath, B.M.; Braun, D.; Dominici, F. Exposure to air pollution and COVID-19 mortality in the United States: A nationwide cross-sectional study. Epidemiology 2020, 4. [CrossRef]

9. Travaglio, M.; Yu, Y.; Popovic, R.; Leal, N.S.; Martins, L.M. Links between air pollution and COVID-19 in England. Toxicology 2020. [CrossRef]

10. Conticini, E.; Frediani, B.; Caro, D. Can atmospheric pollution be considered a co-factor in extremely high level of SARS-CoV-2 lethality in Northern Italy? Environ. Pollut. 2020, 261, 114465. [CrossRef]

11. Contini, D.; Costabile, F. Does air pollution influence COVID-19 outbreaks? Atmosphere 2020, 11, 377. [CrossRef]

12. Mitsakou, C.; Dimitroulopoulou, S.; Heaviside, C.; Katsouyanni, K.; Samoli, E.; Rodopoulou, S.; Costa, C.; Almendra, R.; Santana, P.; Dell'Olmo, M.M.; et al. Environmental public health risks in European metropolitan areas within the EURO-HEALTHY project. Sci. Total Environ. 2019, 658, 1630-1639. [CrossRef] [PubMed]

13. Samoli, E.; Stergiopoulou, A.; Santana, P.; Rodopoulou, S.; Mitsakou, C.; Dimitroulopoulou, C.; Bauwelinck, M.; de Hoogh, K.; Costa, C.; Marí-Dell'Olmo, M.; et al. Spatial variability in air pollution exposure in relation to socioeconomic indicators in nine European metropolitan areas: A study on environmental inequality. Environ. Pollut. 2019, 249, 345-353. [CrossRef] [PubMed]

14. European Environment Agency. Air Quality in Europe: 2019 Report; European Environment Agency: Copenhagen, Denmark, 2019; ISBN 978-92-9480-088-6.

15. Madrid Municipality Inventario de Emisiones de Contaminantes a la Atmósfera en el Municipio de Madrid 2017. Available online: https://www.madrid.es/UnidadesDescentralizadas/Sostenibilidad/EspeInf/ EnergiayCC/04CambioClimatico/4aInventario/Ficheros/Inventario_emisiones_INV2017.pdf (accessed on 29 May 2020).

16. AirParif Les Emissions en Quelques Chiffres. Available online: https://www.airparif.asso.fr/etat-air/air-etclimat-quelques-chiffres (accessed on 29 May 2020).

17. London Datastore London Atmospheric Emissions (LAEI) 2016. Available online: https://data.london.gov. uk/dataset/london-atmospheric-emissions-inventory--laei--2016 (accessed on 29 May 2020).

18. Zhang, R.; Zhang, Y.; Lin, H.; Feng, X.; Fu, T.-M.; Wang, Y. NOx emission reduction and recovery during COVID-19 in East China. Atmosphere 2020, 11, 433. [CrossRef]

19. Tobías, A.; Carnerero, C.; Reche, C.; Massagué, J.; Via, M.; Minguillón, M.C.; Alastuey, A.; Querol, X. Changes in air quality during the lockdown in Barcelona (Spain) one month into the SARS-CoV-2 epidemic. Sci. Total Environ. 2020, 726, 138540. [CrossRef] [PubMed]

20. Giechaskiel, B.; Clairotte, M.; Valverde-Morales, V.; Bonnel, P.; Kregar, Z.; Franco, V.; Dilara, P. Framework for the assessment of PEMS (portable emissions measurement systems) uncertainty. Environ. Res. 2018, 166, 251-260. [CrossRef]

21. Eurostat Statistics Explained: Passenger Cars in EU. Available online: https://ec.europa.eu/eurostat/statisticsexplained/images/1/11/SE_Passenger_cars_in_the_EU_update2019.xlsx (accessed on 29 May 2020). 
22. Weiss, M.; Bonnel, P.; Hummel, R.; Provenza, A.; Manfredi, U. On-road emissions of light-duty vehicles in Europe. Environ. Sci. Technol. 2011, 45, 8575-8581. [CrossRef]

23. Valverde, V.; Mora, B.A.; Clairotte, M.; Pavlovic, J.; Suarez-Bertoa, R.; Giechaskiel, B.; Astorga-LLorens, C.; Fontaras, G. Emission factors derived from 13 Euro $6 \mathrm{~b}$ light-duty vehicles based on laboratory and on-road measurements. Atmosphere 2019, 10, 243. [CrossRef]

24. Clairotte, M.; Valverde, V.; Bonnel, P.; Giechaskiel, P.; Carriero, M.; Otura, M.; Fontaras, G.; Pavlovic, J.; Martini, G.; Krasenbrink, A. Joint Research Centre 2017 Light-Duty Vehicles Emissions Testing Contribution to the EU Market Surveillance: Testing Protocols and Vehicle Emissions Performance; Publications Office of the EU: Brussels, Belgium, 2018; ISBN 978-92-79-90600-8.

25. Franco, V.; Posada, F.; German, J.; Mock, P. Real world exhaust emissions from modern diesel cars. Communications 2014, 49, 847129-102.

26. Degraeuwe, B.; Weiss, M. Does the New European Driving Cycle (NEDC) really fail to capture the NOx emissions of diesel cars in Europe? Environ. Pollut. 2017, 222, 234-241. [CrossRef]

27. Leach, F.C.P.; Peckham, M.S.; Hammond, M.J. Identifying NOx hotspots in transient urban driving of two diesel buses and a diesel car. Atmosphere 2020, 11, 355. [CrossRef]

28. Ma, C.; Wu, L.; Mao, H.; Fang, X.; Wei, N.; Zhang, J.; Yang, Z.; Zhang, Y.; Lv, Z.; Yang, L. Transient characterization of automotive exhaust emission from different vehicle types based on on-road measurements. Atmosphere 2020, 11, 64. [CrossRef]

29. Giechaskiel, B.; Suarez-Bertoa, R.; Lahde, T.; Clairotte, M.; Carriero, M.; Bonnel, P.; Maggiore, M. Emissions of a Euro $6 \mathrm{~b}$ diesel passenger car retrofitted with a solid ammonia reduction system. Atmosphere 2019, 10, 180. [CrossRef]

30. Guan, B.; Zhan, R.; Lin, H.; Huang, Z. Review of state of the art technologies of selective catalytic reduction of NOx from diesel engine exhaust. Appl. Therm. Eng. 2014, 66, 395-414. [CrossRef]

31. Giechaskiel, B.; Mamakos, A.; Andersson, J.; Dilara, P.; Martini, G.; Schindler, W.; Bergmann, A. Measurement of automotive nonvolatile particle number emissions within the European legislative framework: A review. Aerosol Sci. Technol. 2012, 46, 719-749. [CrossRef]

32. Burtscher, H. Physical characterization of particulate emissions from diesel engines: A review. J. Aerosol Sci. 2005, 36, 896-932. [CrossRef]

33. Demuynck, J.; Favre, C.; Bosteels, D.; Bunar, F.; Spitta, J.; Kuhrt, A. Diesel Vehicle with Ultra-Low NOx Emissions on the Road; No. 2019-24-0145; SAE: Warrendale, PA, USA, 2019.

34. Simonen, P.; Kalliokoski, J.; Karjalainen, P.; Rönkkö, T.; Timonen, H.; Saarikoski, S.; Aurela, M.; Bloss, M.; Triantafyllopoulos, G.; Kontses, A.; et al. Characterization of laboratory and real driving emissions of individual Euro 6 light-duty vehicles-Fresh particles and secondary aerosol formation. Environ. Pollut. 2019, 255, 113175. [CrossRef] [PubMed]

35. Williams, R.; Andersson, J.; Hamje, H.; Ziman, P.; Kar, K.; Fittavolini, C.; Pellegrini, L.; Gunther, G.; Oliva, F.; Van de Heijning, P. Impact of Demanding Low Temperature Urban Operation on the Real Driving Emissions Performance of Three European Diesel Passenger Cars; No. 2018-01-1819; SAE: Warrendale, PA, USA, 2018.

36. Suarez-Bertoa, R.; Valverde-Morales, V.; Clairotte, M.; Pavlovic, J.; Giechaskiel, B.; Franco, V.; Kregar, Z.; Astorga-LLorens, C. On-road emissions of passenger cars beyond the boundary conditions of the real-driving emissions test. Environ. Res. 2019, 108572. [CrossRef]

37. Leblanc, M.; Noel, L.; R'Mili, B.; Boréave, A.; D'Anna, B.; Raux, S. Impact of engine warm-up and DPF active regeneration on regulated \& unregulated emissions of a Euro 6 Diesel SCR equipped vehicle. J. Earth Sci. Geotechnol. Eng. 2016, 6, 29-50.

38. Transport \& Environment. New Diesels, New Problems. Report 2020. Available online: https://www. transportenvironment.org/publications/new-diesels-new-problems (accessed on 17 June 2020).

39. Giechaskiel, B.; Munoz-Bueno, R.; Rubino, L.; Manfredi, U.; Dilara, P.; De Santi, G.; Andersson, J. Particle Measurement Programme (PMP): Particle Size and Number Emissions before, during and after Regeneration Events of a Euro 4 DPF Equipped Light-Duty Diesel Vehicle; No. 2007-01-1944; SAE: Warrendale, PA, USA, 2007.

40. Giechaskiel, B.; Lähde, T.; Suarez-Bertoa, R.; Clairotte, M.; Grigoratos, T.; Zardini, A.; Perujo, A.; Martini, G. Particle number measurements in the European legislation and future JRC activities. Combust. Engines 2018, 174, 3-16. [CrossRef]

41. Giechaskiel, B. Particle number emissions of a diesel vehicle during and between regeneration events. Catalysts 2020, 10, 587. [CrossRef] 
42. Erisman, J.W.; Schaap, M. The need for ammonia abatement with respect to secondary PM reductions in Europe. Environ. Pollut. 2004, 129, 159-163. [CrossRef]

43. Stocker, T. Climate Change 2013: The Physical Science Basis: Working Group I Contribution to the Fifth Assessment Report of the Intergovernmental Panel on Climate Change; Cambridge University Press: New York, NY, USA, 2014; ISBN 978-1-107-05799-9.

44. Kim, M.J. Sensitivity of nitrate aerosol production to vehicular emissions in an urban street. Atmosphere 2019, 10, 212. [CrossRef]

45. Valverde, V.; Clairotte, M.; Bonnel, P.; Giechaskiel, P.; Carriero, M.; Otura, M.; Gruening, C.; Fontaras, G.; Pavlovic, J.; Martini, G.; et al. Joint Research Centre 2018 Light-Duty Vehicles Emissions Testing: Contribution to the EU Market Surveillance: Testing Protocols and Vehicle Emissions Performance; Publications Office of the European Union: Brussels, Belgium, 2019; ISBN 978-92-76-12333-0.

46. Suarez-Bertoa, R.; Pechout, M.; Vojtíšek, M.; Astorga, C. Regulated and non-regulated emissions from Euro 6 diesel, gasoline and CNG vehicles under real-world driving conditions. Atmosphere 2020, 11, 204. [CrossRef]

47. Giechaskiel, B.; Cresnoverh, M.; Jörgl, H.; Bergmann, A. Calibration and accuracy of a particle number measurement system. Meas. Sci. Technol. 2010, 21, 045102. [CrossRef]

48. Giechaskiel, B.; Bonnel, P.; Perujo, A.; Dilara, P. Solid particle number (SPN) portable emissions measurement systems (PEMS) in the European legislation: A review. IJERPH 2019, 16, 4819. [CrossRef] [PubMed]

49. AVL CONCERTO: Lab Data Intelligence with AVL CONCERTO. Available online: https://www.avl.com/-/ avl-concerto-5- (accessed on 29 May 2020).

50. JRC EMROAD. Available online: https://circabc.europa.eu/sd/a/efc8a97c-5281-4483-9b93-da79cd197f14/ EMROAD_6_03.zip (accessed on 29 May 2020).

51. Varella, R.; Giechaskiel, B.; Sousa, L.; Duarte, G. Comparison of Portable Emissions Measurement Systems (PEMS) with Laboratory Grade Equipment. Appl. Sci. 2018, 8, 1633. [CrossRef]

52. Giechaskiel, B.; Casadei, S.; Mazzini, M.; Sammarco, M.; Montabone, G.; Tonelli, R.; Deana, M.; Costi, G.; Di Tanno, F.; Prati, M.; et al. Inter-laboratory correlation exercise with portable emissions measurement systems (PEMS) on chassis dynamometers. Appl. Sci. 2018, 8, 2275. [CrossRef]

53. European Commission Commission Regulation (EU) 2018/1832 2018. Available online: https://eur-lex.europa. eu/legal-content/EN/TXT/PDF/?uri=CELEX:32018R1832\&from=FR (accessed on 28 May 2020).

54. Kwon, S.; Park, Y.; Park, J.; Kim, J.; Choi, K.-H.; Cha, J.-S. Characteristics of on-road NOx emissions from Euro 6 light-duty diesel vehicles using a portable emissions measurement system. Sci. Total Environ. 2017, 576, 70-77. [CrossRef]

55. O'Driscoll, R.; Stettler, M.E.J.; Molden, N.; Oxley, T.; ApSimon, H.M. Real world $\mathrm{CO}_{2}$ and NOx emissions from 149 Euro 5 and 6 diesel, gasoline and hybrid passenger cars. Sci. Total Environ. 2018, 621, 282-290. [CrossRef]

56. Triantafyllopoulos, G.; Dimaratos, A.; Ntziachristos, L.; Bernard, Y.; Dornoff, J.; Samaras, Z. A study on the $\mathrm{CO}_{2}$ and NOx emissions performance of Euro 6 diesel vehicles under various chassis dynamometer and on-road conditions including latest regulatory provisions. Sci. Total Environ. 2019, 666, 337-346. [CrossRef] [PubMed]

57. Ko, J.; Myung, C.-L.; Park, S. Impacts of ambient temperature, DPF regeneration, and traffic congestion on NOx emissions from a Euro 6-compliant diesel vehicle equipped with an LNT under real-world driving conditions. Atmos. Environ. 2019, 200, 1-14. [CrossRef]

58. Vojtíšek-Lom, M.; Beránek, V.; Klír, V.; Jindra, P.; Pechout, M.; Voříšek, T. On-road and laboratory emissions of $\mathrm{NO}, \mathrm{NO}_{2}, \mathrm{NH}_{3}, \mathrm{~N}_{2} \mathrm{O}$ and $\mathrm{CH}_{4}$ from late-model EU light utility vehicles: Comparison of diesel and CNG. Sci. Total Environ. 2018, 616, 774-784. [CrossRef]

59. Olsen, D.B.; Kohls, M.; Arney, G. Impact of oxidation catalysts on exhaust $\mathrm{NO}_{2} / \mathrm{NOx}$ ratio from lean-burn natural gas engines. J. Air Waste Manag. Assoc. 2010, 60, 867-874. [CrossRef] [PubMed]

60. Li, H.; Ropkins, K.; Andrews, G.E.; Daham, B.; Bell, M.; Tate, J.; Hawley, G. Evaluation of a FTIR Emission Measurement System for Legislated Emissions Using a SI Car; No. 2006-01-3368; SAE: Warrendale, PA, USA, 2006.

61. Leach, F.; Davy, M.; Peckham, M. Cyclic $\mathrm{NO}_{2}: \mathrm{NOx}$ ratio from a diesel engine undergoing transient load steps. Int. J. Engine Res. 2019, 146808741983320. [CrossRef]

62. O’Driscoll, R.; ApSimon, H.M.; Oxley, T.; Molden, N.; Stettler, M.E.J.; Thiyagarajah, A. A portable emissions measurement system (PEMS) study of NOx and primary $\mathrm{NO}_{2}$ emissions from Euro 6 diesel passenger cars and comparison with COPERT emission factors. Atmos. Environ. 2016, 145, 81-91. [CrossRef] 
63. Suarez-Bertoa, R.; Mendoza-Villafuerte, P.; Riccobono, F.; Vojtisek, M.; Pechout, M.; Perujo, A.; Astorga, C. On-road measurement of $\mathrm{NH}_{3}$ emissions from gasoline and diesel passenger cars during real world driving conditions. Atmos. Environ. 2017, 166, 488-497. [CrossRef]

64. Suarez-Bertoa, R.; Astorga, C. Isocyanic acid and ammonia in vehicle emissions. Transp. Res. Part D Transp. Environ. 2016, 49, 259-270. [CrossRef]

65. Suarez-Bertoa, R.; Kousoulidou, M.; Clairotte, M.; Giechaskiel, B.; Nuottimäki, J.; Sarjovaara, T.; Lonza, L. Impact of HVO blends on modern diesel passenger cars emissions during real world operation. Fuel 2019, 235, 1427-1435. [CrossRef]

66. Pechout, M.; Kotek, M.; Jindra, P.; Macoun, D.; Hart, J.; Vojtisek-Lom, M. Comparison of hydrogenated vegetable oil and biodiesel effects on combustion, unregulated and regulated gaseous pollutants and DPF regeneration procedure in a Euro6 car. Sci. Total Environ. 2019, 696, 133748. [CrossRef]

67. Bielaczyc, P.; Szczotka, A.; Woodburn, J. An overview of cold start emissions from direct injection spark-ignition and compression ignition engines of light duty vehicles at low ambient temperatures. Combust. Engines 2013, 154, 96-103.

68. Gao, J.; Tian, G.; Sorniotti, A.; Karci, A.E.; Di Palo, R. Review of thermal management of catalytic converters to decrease engine emissions during cold start and warm up. Appl. Therm. Eng. 2019, 147, 177-187. [CrossRef]

69. Badshah, H.; Khalek, I.A. Solid particle emissions from vehicle exhaust during engine start-up. SAE Int. J. Engines 2015, 8. [CrossRef]

70. Mamakos, A.; Martini, G.; Manfredi, U. Assessment of the legislated particle number measurement procedure for a Euro 5 and a Euro 6 compliant diesel passenger cars under regulated and unregulated conditions. J. Aerosol Sci. 2013, 55, 31-47. [CrossRef]

71. Giechaskiel, B.; Riccobono, F.; Vlachos, T.; Mendoza-Villafuerte, P.; Suarez-Bertoa, R.; Fontaras, G.; Bonnel, P.; Weiss, M. Vehicle emission factors of solid nanoparticles in the laboratory and on the road using portable emission measurement systems (PEMS). Front. Environ. Sci. 2015, 3. [CrossRef]

72. Zinola, S.; Raux, S.; Leblanc, M. Persistent Particle Number Emissions Sources at the Tailpipe of Combustion Engines; No. 2016-01-2283; SAE: Warrendale, PA, USA, 2016.

73. Beatrice, C.; Costagliola, M.A.; Guido, C.; Napolitano, P.; Prati, M.V. How Much Regeneration Events Influence Particle Emissions of DPF-Equipped Vehicles; No. 2017-24-0144; SAE: Warrendale, PA, USA, 2017.

74. Rose, K.; Hamje, H.; Jansen, L.; Fittavolini, C.; Clark, R.; Cardenas Almena, M.D.; Katsaounis, D.; Samaras, C.; Geivanidis, S.; Samaras, Z. Impact of FAME Content on the Regeneration Frequency of diesel particulate filters (DPFs). SAE Int. J. Fuels Lubr. 2014, 7, 563-570. [CrossRef]

75. Chappell, E.; Burke, R.; Lu, P.; Gee, M.; Williams, R. Analysis of a diesel passenger car behavior on-road and over certification duty cycles. SAE Int. J. Engines 2016, 9, 2201-2214. [CrossRef]

76. Pajdowski, P.; Puchałka, B. The process of diesel particulate filter regeneration under real driving conditions. IOP Conf. Ser.: Earth Environ. Sci. 2019, 214, 012114. [CrossRef]

77. Thompson, G.J.; Carder, D.K.; Besch, M.C.; Thiruvengadam, A.; Kappanna, H.K. In-Use Emissions Testing of Light-Duty Diesel Vehicles in the United States; SAE: Warrendale, PA, USA, 2014.

78. Viswanathan, S.; George, S.; Govindareddy, M.; Heibel, A. Advanced Diesel Particulate Filter Technologies for Next Generation Exhaust Aftertreatment Systems; No. 2020-01-1434; SAE: Warrendale, PA, USA, 2020.

79. Cumaranatunge, L.; Chiffey, A.; Stetina, J.; McGonigle, K.; Repley, G.; Lee, A.; Chatterjee, S. A study of the soot combustion efficiency of an $\mathrm{SCRF}^{\circledR}$ catalyst vs. a CSF during active regeneration. Emiss. Control Sci. Technol. 2017, 3, 93-104. [CrossRef]

80. Otsuki, Y.; Tochino, S.; Kondo, K.; Haruta, K. Portable Emissions Measurement System for Solid Particle Number Including Nanoparticles Smaller than 23 nm; No. 2017-01-2402; SAE: Warrendale, PA, USA, 2017.

81. Filippo, A.D.; Maricq, M.M. Diesel nucleation mode particles: Semivolatile or solid? Environ. Sci. Technol. 2008, 42, 7957-7962. [CrossRef]

82. Giechaskiel, B.; Lähde, T.; Gandi, S.; Keller, S.; Kreutziger, P.; Mamakos, A. Assessment of 10-nm particle number (PN) portable emissions measurement systems (PEMS) for future regulations. IJERPH 2020, 17, 3878. [CrossRef] [PubMed]

83. Yamada, H.; Inomata, S.; Tanimoto, H. Mechanisms of increased particle and VOC emissions during DPF active regeneration and practical emissions considering regeneration. Environ. Sci. Technol. 2017, 51, 2914-2923. [CrossRef] [PubMed] 
84. Giechaskiel, B.; Manfredi, U.; Martini, G. Engine exhaust solid sub-23 nm particles: I. literature survey. SAE Int. J. Fuels Lubr. 2014, 7, 950-964. [CrossRef]

85. Giechaskiel, B. Differences between tailpipe and dilution tunnel sub-23 nm nonvolatile (solid) particle number measurements. Aerosol Sci. Technol. 2019, 53, 1012-1022. [CrossRef]

86. Giechaskiel, B.; Mamakos, A.; Woodburn, J.; Szczotka, A.; Bielaczyc, P. Evaluation of a $10 \mathrm{~nm}$ particle number portable emissions measurement system (PEMS). Sensors 2019, 19, 5531. [CrossRef] [PubMed]

87. Giechaskiel, B. Effect of sampling conditions on the sub-23 $\mathrm{nm}$ nonvolatile particle emissions measurements of a moped. Appl. Sci. 2019, 9, 3112. [CrossRef]

88. Yang, J.; Pham, L.; Johnson, K.C.; Durbin, T.D.; Karavalakis, G.; Kittelson, D.; Jung, H. Impacts of exhaust transfer system contamination on particulate matter measurements. Emiss. Control Sci. Technol. 2020. [CrossRef]

(C) 2020 by the authors. Licensee MDPI, Basel, Switzerland. This article is an open access article distributed under the terms and conditions of the Creative Commons Attribution (CC BY) license (http://creativecommons.org/licenses/by/4.0/). 